\author{
ANDRZEJ PLESZCZYŃSKI \\ Uniwersytet Marii Curie-Skłodowskiej \\ Lublin
}

\title{
KRYZYS I UPADEK WCZESNYCH PAŃSTW SŁOWIAŃSKICH ORAZ ICH ODBUDOWA (IX-XI WIEK). ZARYS PROBLEMU
}

\begin{abstract}
Abstrakt: Artykuł jest analizą kryzysów, które miały miejsce $\mathrm{w}$ państwach środkowoeuropejskich w IX-XI w. Uzasadniano w nim tezę o strukturalnych, ekonomiczno-politycznych przyczynach załamywania się państw stworzonych przez Przemyślidów, Piastów, Arpadów i inne dynastie regionu. Kryzys wiązał się z wyczerpaniem możliwości istnienia państwa ekstensywnie, często rabunkowo eksploatującego poddanych, charakterystycznego dla wielu ówczesnych wczesnych organizacji politycznych. Te akurat funkcjonujące w Europie Środkowej w największym stopniu czerpały wzory z państwowości koczowniczych. Kryzys w tym regionie przetrwały jedynie te organizmy polityczne, które zdołały zmienić zasady sprawowania władzy i zmodernizować je, racjonalizując sposób eksploatacji poddanych, inspirując się rozwiązaniami stosowanymi na obszarach dawnego państwa Franków.
\end{abstract}

Słowa kluczowe: państwa słowiańskie, średniowiecze, kryzys władzy, bunty pogańskie, ustrój państwa.
Abstract: The article is an analysis of the crises that occurred in Central European states in the ninth to eleventh centuries. A thesis is proved about structural, economic and political causes of the collapse of states formed by the Přemyslids, Piasts, Árpáds and other dynasties of the region. The crisis was related to the exhaustion of the possibility of existence of state which extensively, often wastefully, exploited its subjects, characteristic of many early political entities. Those functioning in Central Europe were mostly modelled on nomadic states. Only those political entities that were able to transform their principles of governance and to modernize them, improving their ways of exploitation of the subjects, drawing inspiration from practices known in the territories of the former Frankish kingdom, survived the crisis in the region.

Keywords: Slavic states, the Middle Ages, crisis of power, pagan revolts, state organisation. 
Jest zastanawiające, że w zasadzie wszystkie państwa środkowej, południowej i wschodniej Europy, przeważnie słowiańskie, ale przecież nie tylko, istniejące we wcześniejszym średniowieczu, przeżywały po okresie potęgi i wielkiego wzrostu terytorialnego głębokie załamanie, które często kończyło się ich upadkiem. Kryzysy miały przede wszystkim charakter polityczny - o tym przynajmniej informują nas źródła. Czytamy także, że zwykle dochodziło do buntów przeciwko nowej religii chrześcijaństwu, które było mniej więcej pół wieku przed załamywaniem się państwowości zaprowadzane, albo zakorzeniało się głębiej, w danej społeczności.

Pewna powtarzalność okoliczności i podobieństwa charakteru zapaści organizacji politycznych, pomimo tego, iż zdarzały się one na różnych obszarach i w nieco różnych czasach, rodzą przypuszczenia, że za tymi buntami wobec władzy i jej kryzysami mogły stać zbliżone przyczyny społeczne oraz ekonomiczne. Zadaniem niniejszego szkicu będzie zatem prześledzenie najważniejszych informacji dotyczących zjawiska załamywania się władzy centralnej w różnych państwach Europy Środkowej, Południowej i Wschodniej w okresie od IX po XI wiek ${ }^{1}$. Unikając bezproduktywnego wyliczania poglądów generacji badaczy, postaramy się zwięźle przedstawić oraz zweryfikować istniejące próby wyjaśnienia fenomenu i dorzucić do nich pewne tezy formułowane w oparciu o dane płynące z nowszych dociekań. Wprawdzie ani forma niniejszego szkicu, ani rozmiar omawianego zjawiska, jego niejasność nie pozwalają na kreowanie jednoznacznie pewnych wyjaśnień kwestii, ale jednak spróbujemy zastanowić się, jakie wspólne przyczyny mogły stać za różnymi przypadkami kryzysów państwowości środkowoeuropejskich, zwracając oczywiście uwagę na ewentualne odmienności.

Problem jest rozległy, złożony i trudny. Możemy zatem pokusić się jedynie o to, by czynić duże uogólnienia i zaproponować interpretację, która może wzbudzić wątpliwości czy sprowokować głosy sprzeciwu.

${ }^{1}$ Problem tu rozwijany interesował, co poniekąd oczywiste, od dawna wielu badaczy - zestawienie bibliograficzne (głównie polskich) starszych prac znajdziemy w: D. Borawska, Kryzys monarchii wczesnopiastowskiej w latach trzydziestych XI w. Studia, Warszawa 1964; nowsze, o nieco węższym spectrum: G. Myśliwski, Feudalizm - „rewolucja feudalna" - kryzys władzy w Polsce XI - początku XII w. Punkt widzenia mediewistyki anglojęzycznej, PH 93, 2002, 1, s. 73-102 (zwłaszcza s. 94-102); zob. także: H.J. Lang, The Fall of the Monarchy of Mieszko II, Lambert, „Speculum” 49, 1974, s. 623-639; kwestię omawiano także, wraz z zestawieniami źródeł i literatury dotyczącymi całego regionu Europy Wschodniej i Środkowej w: B. Krzemieńska, Krize českého státu na přelomu tisíciletí, „Československy் Časopis Historickỳ” 18, 1970, 6, s. 497-532; J. Žemlička, Expanse, krize a obnova Čech v letech 935-1055 (K systémovým proměnám raných států ve střední Evropě), „Český časopis historicky்” 93, 1995, s. 205-222. 
Dyskusja zawsze jednak jest cenna - tym bardziej że kwestia jest ciekawa i ważna, a przy tym dawno niepodejmowana.

Już teraz, na początku niniejszych rozważań, trzeba zaznaczyć, że łączenie w ramach jednej analizy różnych tworów politycznych, istniejących nieraz w dużej odległości od siebie, czasami też w różnym czasie, podyktowane zostało nie tylko potrzebami zbudowania pewnych syntetycznych uogólnień, które - autor ma nadzieję - będą mogły się obronić przed krytyką opartą o ustalenia partykularne. Poważną przesłanką, dozwalającą na czynienie tu generalizacji, jest świadomość tego, że na całym obszarze Słowiańszczyzny wczesnośredniowiecznej do początku XI w. istniał jeszcze w zasadzie jeden język i zapewne podobna cywilizacja ${ }^{2}$. Procesy, które ostatecznie w XII w. rozdzieliły Słowian na różne grupy językowe, kulturowe, religijne i polityczne, zaczęły być lepiej zauważalne dopiero na przełomie pierwszego i drugiego tysiąclecia naszej ery ${ }^{3}$. Utrudnia natomiast nam analizę to, że w istocie losy państw regionu w interesującym nas czasie w szczegółach są dość różne, a podobieństw strukturalnych ich dziejów musimy się domyślać na podstawie niepełnych przesłanek źródeł pisanych i równie niejasnych wyników badań archeologicznych.

Z uwagi na rozległość naszej kwestii oraz konieczność zwięzłości dowodzenia, zmuszeni jesteśmy ponadto dokonać wyboru, by z wielu przykładów historii państwowości środkowoeuropejskich we wcześniejszym średniowieczu przedstawić te - wydaje się - najistotniejsze, najbardziej reprezentatywne dla snutych tu rozważań. Nie da się też zachować równowagi komentarzy dotyczących wybranych państw niektóre będą przedstawione obszerniej, inne szkicowo. Zadecydowało o takim kształcie wywodu znaczenie opisywanych zjawisk dla snutych tu rozważań. Ze względu na pewną logikę kompozycji niniejszego szkicu, najpierw zaprezentujemy dane historyczne, później dopiero

${ }^{2}$ F. Dvornik, The Slavs. Their Early History and Civilization, Boston 1956; A.P. Vlasto, The Entry of the Slavs into Christendom. An Introduction to the Medieval History of the Slavs, Cambridge 1970; zob. także: F. Curta, The Slavic Lingua franca (Linguistic Notes of an Archeologist Turned Historian), „East Central Europe” 31, 2004, 1, s. 125-148; L. Leciejewicz, Nowa postać świata. Narodziny średniowiecznej cywilizacji europejskiej, Wrocław 2000, s. 148 nn.; przegląd wczesnych państwowości regionu np.: P. Urbańczyk, Początki państw wczesnośredniowiecznych w Europie Środkowowschodniej, w: Ziemie polskie w X wieku i ich znaczenie w kształtowaniu się nowej mapy Europy, red. H. Samsonowicz, Kraków 2000, s. 53-70.

${ }_{3}$ P.M. Barford, The Early Slavs. Culture and Society in Early Medieval Eastern Europe, Ithaca-New York 2001, s. 89 nn.; zob. także: H. Dalewska-Greń, Języki słowiańskie, Warszawa 2012, s. 560 nn.; Z. Gołąb, o pochodzeniu Słowian w świetle faktów językowych, Kraków 2004, s. 11-16. 
zastanowimy się, jak je interpretować w kontekście postawionego tu problemu tytułowego.

Zacznijmy od pierwszego, znanego, dużego i silnego państwa zachodniosłowiańskiego, od Wielkich Moraw ${ }^{4}$. Powstanie tego tworu politycznego umożliwiło rozbicie w latach 805-806 przez armie frankijskie kaganatu awarskiego ${ }^{5}$. Centrum państwa koczowników tureckich od drugiej połowy VI w. znajdowało się mniej więcej na terenie dzisiejszych Węgier. Wiemy, że Awarowie podporządkowali sobie rozległe obszary słowiańskie położone w środkowej Europie oraz na Bałkanach - granic ich wpływów nie da się jednak ściślej wyznaczyć6. Są informacje świadczące o tym, że imperium koczowników potrafiło werbować oddziały słowiańskie nawet z odległych krańców regionu, wykorzystując je jako siły pomocnicze swojej armii w walkach z Bizantyjczykami ${ }^{7}$.

Próżnię polityczną, jaka wytworzyła się po upadku państwowości awarskiej w regionie środowego biegu Dunaju, zajęły władztwa słowiańskie, spośród których najbardziej prężna okazała się monarchia wielkomorawska. Już około roku 830 pierwszy znany władca tego kraju, Mojmir I (ok. 830-846), podbił i włączył do swojego państwa znaczną część zachodniej Słowacji, na terenie której istniało księstwo Nitry ${ }^{8}$. 0 zdobyczach terytorialnych następnego panującego, Rościsława (846-870), wiadomo mało. Znana jest jedynie jego dbałość o chrystianizację ludności, która zaowocowała sprowadzeniem w roku 863 z Bizancjum słynnych

${ }^{4}$ Podstawowe informacje o tym państwie np.: K. Polek, Państwo wielkomorawskie i jego sassiedzi, Kraków 1994; D. Třeštík, Powstanie Wielkich Moraw. Morawianie, Czesi i Europa Środkowa w latach 791-871, Warszawa 2009; M. Betti, The Making of Christian Moravia (858-882). Papal Power and Political Reality, Leiden-Boston 2013 (East Central and Eastern Europe in the Middle Ages, 450-1450, nr 24).

${ }^{5}$ H. Schutz, The Carolingians in Central Europe, their History, Arts and Architecture. A Cultural History of Central Europe, 750-900, Leiden-Boston 2004, s. 122 n.; A.P. Vlasto, op. cit., s. 20 nn.; N. Berend, P. Wiszewski, P. Urbańczyk, Central Europe in the High Middle Ages, Bohemia, Hungary and Poland c. 900-c. 1300, Cambridge 2013, s. 50-56.

${ }^{6}$ W. Szymański, E. Dąbrowska, Awarzy, Węgrzy, Wrocław 1979, s. 32 nn.; D. Sinior, The Avars, w: Cambridge History of Early Inner Asia, red. D. Sinior [et al.], Cambridge 1990, s. 206-220; zob. także zbiór studiów: The Other Europe in the Middle Ages. Avars, Bulgars, Khazars and Cumans, red. F. Curta, R. Kovalev, Leiden-Boston 2008.

7 Słowiańszczyzna starożytna i wczesnośredniowieczna, red. G. Labuda, Poznań 1999, s. 74-75 (Teofylakt Simokattes, O ustroju Słowian nadbałtyckich); zob. także: F. Curta, Avar Blitzkrieg, Slavic and Bulgar Raiders, and Roman Special Ops. Mobile Wariors in the $6^{\text {th }}$-Century Balkans, w: Central Eurasia in the Middle Ages. Studies in Honour of Peter B. Golden, red. I. Zimonyi, O. Karatay, Wiesbaden 2016, s. 69-90.

${ }^{8}$ Użyta tu nazwa jest współczesna, w istocie mało wiemy o ówczesnej terminologii, zob. np.: Slovakia in History, red. M. Teich, D. Kováč, M.D. Brown, Cambridge 2011, s. 17 n.; L.J. Kościelak, Historia Słowacji, Wrocław 2010, s. 84 n. 
tzw. Braci Sołuńskich, Konstantyna i Metodego, którzy byli w stanie zbudować słowiańską hierarchię kościelną kraju . Dopiero podboje jego bratanka, Świętopełka I (870-894), są lepiej poświadczone źródłowo ${ }^{10}$. Prowadził on szeroko zakrojoną ekspansję i pod koniec panowania pod jego władzą znalazły się wielkie obszary z południem dzisiejszej Polski (Śląsk, Małopolska) ${ }^{11}$, częścią Łużyc ${ }^{12}$, Czechami, terytorium dzisiejszych Węgier i być może nawet północne regiony dzisiejszej Serbii ${ }^{13}$.

Mało wiemy, co działo się na Morawach po śmierci Świętopełka, pewne jest jedynie to, że jego państwo uległo szybkiemu rozkładowi. Źródła donoszą o walkach pomiędzy synami zmarłego władcy: Mojmirem (II), który został władcą zwierzchnim kraju, i Świętopełkiem (II), w którego władaniu znajdowało się dawne księstwo nitrzańskie. Osłabienie monarchii wielkomorawskiej wykorzystali Węgrzy, którym wcześniej udało się około 896 r. przedostać z terenów nadczarnomorskich przez Karpaty i zająć stepy Kotliny Panońskiej ${ }^{14}$. Los ostatnich dynastów morawskich jest niejasny. Niektórzy uważają, że opuścili kraj, w którym stracili poparcie społeczne; inni, że zginęli (pewnie w walkach z koczownikami). Pewne jest, że ich państwo upadło pomiędzy latami $904-906^{15}$.

Niewiele tylko młodszym niż Wielkie Morawy organizmem politycznym była dawna Serbia, powstała - z grubsza rzecz biorąc - na obszarze

9 J. Leśny, Konstantyn i Metody. Apostołowie Słowian. Dzieło i jego losy, Poznań 1987, s. 39 nn.; L.E. Havlík, Great Moravia between the Franconians, Byzantium and Rome, w: Centre and Periphery Comparative Studies in Archaeology, red. T. Champion, London-New York 1995, s. 231-240; D. Třeštík, Powstanie Wielkich Moraw, s. 282 nn.

10 I. Panic, Ostatnie lata Wielkich Moraw, Katowice 2003, s. $18 \mathrm{nn}$.

${ }^{11}$ K. Polek, Północna i zachodnia granica państwa wielkomorawskiego $w$ świetle badań historycznych, w: Ślask i Czechy a kultura wielkomorawska, red. K. Wachowski, Wrocław 1997, s. 9-19; oraz K. Wachowski, Północny zasięg ekspansji Wielkich Moraw w świetle badań archeologicznych, w: ibidem, s. 21-23.

${ }^{12}$ Kronika Thietmara, wyd. M.Z. Jedlicki, Poznań 1953, s. 457 (VI,99/60).

${ }^{13}$ Czasami spotyka się w ogóle pogląd, że kolebką, centrum Wielkich Moraw były tereny Serbii w dorzeczu rzeki Morawy (Wielkiej Morawy), południowego dopływu Dunaju - M. Eggers, Das „Großmährische Reich”. Realität oder Fiktion? Eine Neuinterpretation der Quellen zur Geschichte des mittleren Donauraumes im 9. Jahrhundert, Stuttgart 1995 w części jest to powtórzenie dawnych tez: I. Boba, Moravia's History Reconsidered. A Reinterpretation of Medieval Sources, The Hague 1971.

${ }^{14}$ A. Róna-Tas, Hungarians and Europe in the Early Middle Ages. An Introduction to Early Hungarian History, Budapest 1999, s. 319 nn.; К.И. Красильников, Новые даные об етническом составе населения Степного Подониовия в VIII - нач. X в., w: Степи Европы в епоху средневековя, t. 2: Хазарские времия, red. Комитет, Донецк 2001, s. 303-322.

15 I. Panic, op. cit., s. 160-165; Ch.R. Bowlus, Franks, Moravians, and Magyars. The Struggle for the Middle Danube, 788-907, Philadelphia Pa. 1995, s. 242 nn.; M. Wihoda, Morava v 10. století, w: České země v raném středověku, red. P. Sommer, Praha 2006, s. 53-73; A. Róna-Tas, op. cit., s. 339 nn. 
pomiędzy Górami Dynarskimi a środkowym Dunajem. Kraj ten przeżywał okres swojej potęgi pod rządami Mutimira (ok. 855 - ok. 891) ${ }^{16}$. Z woli tego panującego sprowadzono misjonarzy łacińskich, którzy mieli chrystianizować jego poddanych. Mutimirowi udało się nie tylko odeprzeć najazd Bułgarów, ale i rozszerzyć obszar swojego władztwa na Serbów zamieszkałych nad Adriatykiem (Primorje) ${ }^{17}$. Jego następcom nie wiodło się już tak dobrze, ale pomimo walk wewnętrznych i najazdów struktura państwowa przetrwała. W roku 927 władcą kraju został Czasław i wówczas znów doszło do odrodzenia potęgi Serbii. Dopiero klęska Czasława w starciu z Węgrami nad rzeką Sawą w 950 r. i śmierć tego władcy oraz wymarcie dynastii, które zdarzyło się szybko po tym fakcie, wiązały się z zanikiem państwa staroserbskiego, które rozpadło się na szereg drobnych żupanii, uzależnianych z czasem przez ościenne potęgi ${ }^{18}$.

Wiemy, że często upadek jednych państw dawał podstawy pod rozwój innych. Tak było w przypadku Czech. Jeszcze w latach siedemdziesiątych IX w. kraj ten pozostawał pod władzą zwierzchnią Świętopełka wielkomorawskiego. Wówczas stanowił konglomerat różnych księstw ${ }^{19}$. Jednemu z władców tych drobnych państewek, praskiemu Borzywojowi - pierwszemu historycznemu Przemyślidzie, udało się osiągnąć przewagę nad innymi. Stało się tak być może dzięki jego współpracy ze Świętopełkiem morawskim, którego zwierzchność nad sobą uznał. Mniej więcej rok po śmierci Borzywoja (899) Czechy włączono bezpośrednio do Wielkich Moraw. Nie wiemy, co działo się wówczas z Przemyślidami i w jaki sposób przetrwali oni ten okres. Jednak po upadku państwa wielkomorawskiego zdołali oni odzyskać władzę zwierzchnią nad całym krajem, a następnie stopniowo eliminowali innych książąt udzielnych, przejmując ich terytoria. Ostatnim czeskim rodem książęcym, o którym wiemy, że został zniszczony przez Przemyślidów, byli Sławnikowice. Ich główny gród w Libicach zdobyto w 995 r., a przebywających w nim dynastów wymordowano ${ }^{20}$.

16 Ogólnie o pierwszym państwie Serbów: S.M. Ćirković, The Serbs, Malden Mass. 2004, s. 10-20.

17 Ibidem, s. 15 nn.; Ђ. Јанковиђ, Спрско Приморие од 7. до 10. столеђа, Beograd 2007, s. 211 nn.

18 S.M. Ćirković, op. cit., s. 18-19; zob. także: J. Skowronek, M. Tanty, T. Wasilewski, Historia Słowian południowych i zachodnich, Warszawa 1977, s. 40-43 czy: W. Felczak, T. Wasilewski, Historia Jugosławii, Wrocław 1985, s. 64-66.

19 D. Třeštík, Počátky Přemyslovců. Vstup Čechů do dějin (530-935), Praha 1997, s. 312 347; M. Matla-Kozłowska, Pierwsi Przemyślidzi i ich państwo (od X do połowy XI wieku). Ekspansja terytorialna i jej polityczne uwarunkowania, Poznań 2008, s. 15 nn.

${ }^{20}$ J. Sláma, Slavníkovci - významná či okrajová záležitost českých dějin 10. století?, „Archeologické rozhledy" 47, 1995, 2, s. 182-224; J.A. Sobiesiak, Bolesław II Przemyślida (†999). 
Do początku lat osiemdziesiątych X w. Przemyślidzi zdołali nie tylko opanować całą przestrzeń Kotliny Czeskiej, ale i uzależnić północne Morawy oraz obszary dzisiejszej południowej Polski z Wrocławiem i Krakowem $^{21}$. Jednak to była kulminacja ich potęgi w tym okresie. W roku 990 Śląsk z pewnością znajdował się już w składzie państwa Mieszka I22. Podobnie było chyba z Krakowem i Małopolską ${ }^{23}$. Utrata południowych terenów późniejszej Polski wynikła z przegranych wojen (z Niemcami i z Polską). Straty terytorialne Czech musiały nadwerężyć pozycję dynastii w opinii elit kraju. Inną poważną przyczyną wewnętrznego napięcia w Czechach był konflikt władcy z biskupem praskim, Wojciechem Sławnikowicem i jego rodem. Istnieje tradycja, według której biskup praski zabraniał panującemu handlu niewolnikami chrześcijańskimi ${ }^{24}$.

Po śmierci Bolesława II (999) wybuchł przeciw jego następcy, Bolesławowi III, otwarty bunt, który doprowadził do obalenia władcy i osadzenia na tronie praskim niejakiego Władywoja, bliżej nieznanego krewniaka panującego wcześniej Przemyślidy ${ }^{25}$. Po jego zaś szybkiej śmierci, a także po uwięzieniu Bolesława III władzę nad Czechami przejął wiosną $1003 \mathrm{r}$. władca polski Bolesław Chrobry, zaproszony do Pragi przez czeskich możnych, z pominięciem praw do tronu młodocianych synów Bolesława II $^{26}$. Dopiero zbrojna interwencja króla niemieckiego Henryka II, podjęta jesienią 1004 r., usunęła Chrobrego i jego zwolenników z kraju oraz wprowadziła na tron Przemyślidę Jaromira. Kryzys dynastii i jej państwa został

Dynasta i jego państwo, Kraków 2006, s. 122 nn. Czasami się uważa, że Sławnikowice stanowili boczną linię Przemyślidów. Niezależnie od rozstrzygnięcia tej niejasnej kwestii $\mathrm{w}$ drugiej połowie X w. byli oni rywalami politycznymi książąt praskich.

${ }^{21}$ A. Żaki, Kraków wiślański, czeski i wczesnopiastowski, w: Chrystianizacja Polski południowej. Materiały z sesji naukowej odbytej 29 czerwca 1993 r., Kraków 1994, s. 41-71; M. Matla-Kozłowska, op. cit., s. 76-239.

${ }^{22}$ Kronika Thietmara, s. 158 nn. (IV/11-12); J.A. Sobiesiak, op. cit., s. 106 nn.

23 Omówienie kwestii: J.A. Sobiesiak, op. cit., s. 100 nn.

${ }^{24}$ S. Adalberti Pragensis episcopi et martyris vita prior, wyd. J. Karwasińska, Warszawa 1962 (MPH s.n., t. 4, fasc. 1), s. 18 (c. 12); motyw sprzeciwu św. Wojciecha w sprawie sprzedaży niewolników chrześcijańskich Żydom pokazują także sceny z Drzwi Gnieźnieńskich (panele 7 i 8), J. Karwasińska, Drzwi Gnieźnieńskie a rozwój legendy św. Wojciecha, w: eadem, Święty Wojciech, w: Wybór pism, [wyb. i oprac. T. Dunin-Wąsowicz], Warszawa 1996, s. 57-84.

${ }^{25}$ Kwestie te omówione zostały w: B. Krzemieńska, Krize českého státu, s. 497-532; J. Žemlička, op. cit., s. 205-222; autorzy - różniąc się szczegółami wywodu - wskazywali na podobne problemy wiążące się z kryzysem państwa, a mianowicie na jego łupieżczy charakter, wymagający od przywódcy ciągłych zwycięstw i dostarczania drużynnikom zysków z coraz to nowych przedsięwzięć militarnych. Gdy władca nie był w stanie spełnić oczekiwań otoczenia, dochodziło do buntu.

${ }^{26}$ Kronika Thietmara, s. 283 n. (V/23). 
zażegnany tylko dzięki pomocy potężnego sąsiada, od którego zresztą Czechy od tej pory były dość ściśle uzależnione politycznie ${ }^{27}$.

Przenieśmy teraz naszą uwagę na południowo-wschodnie krańce Słowiańszczyzny i przyjrzyjmy się kwestii kryzysu, a następnie upadku państwa starobułgarskiego. W okresie wcześniejszego średniowiecza Bułgaria, której elity - pierwotnie tureckiego pochodzenia - były już poważnie zeslawizowane ${ }^{28}$, przeżywała największy okres swojej potęgi za cara Symeona (893-927) ${ }^{29}$. Wówczas to kraj został trwale schrystianizowany. Po śmierci cara sytuacja Bułgarii układała się różnie. Następcy Symeona stracili znaczną część jego zdobyczy, ale państwu udało się przetrwać. Dynastia zdołała przezwyciężyć nawet ciężki czas lat 967-971, okres najazdów i dominacji nad krajem ruskiego księcia Światosława, planującego nawet z bułgarskiego Perejasławia uczynić stolicę swojego państwa ${ }^{30}$. Dopiero zdecydowane uderzenie cesarza bizantyjskiego

${ }^{27}$ E. Mikušek, Ideové pojeti vztahu českého státu k riši nemecké v dilech dejopiscu 10. a 11. stoléti, „Sbornik Historický” 26, 1979, s. 5-59. Badacze niemieccy, wbrew poglądom Czechów, nie traktują hołdu Władywoja jako precedensu i podkreślają, że Czechy zależne były od króla, nie zaś cesarza - W. Wegener, Böhmen-Mähren und das Reich im Hochmittelalter. Untersuchungen zur Staatsrechtlichen Stellung Böhmens und Mährens im Deutschen Reich des Mittelalters. 919-1253, Köln 1959; H. Jäger, Rechtliche Abhängigkeitsverhältnisse der östlichen Staaten vom Fränkisch-Deutschen Reich (Ende des 8. bis Ende des 11. Jahrhunderts), Frankfurt 1959; czy też: H. Hoffman, Böhmen und das Deutsche Reich im hohen Mittelalter, „Jahrbuch für die Geschichte Mittel - und Ostdeutschlands” 18, 1969, s. 1-62; F. Hegger, Böhmen und das Reich in ottonisch-salischer Zeit, Münster 2006.

${ }^{28}$ W tzw. Relacji Ibrahima ibn Jakuba Bułgarzy uważani byli już za Słowian - Relacja Ibrāhīma ibn Ja'kūba z podróży do krajów słowiańskich w przekazie al-Bekrīego, wyd. T. Kowalski, Kraków 1946 (MPH, II/1), s. 51 n.; slawizacja Bułgarów w znacznym stopniu była związana z ich chrystianizacją - T. Wasilewski, Bizancjum i Słowianie w IX wieku. Studia $z$ dziejów stosunków politycznych i kulturalnych, Warszawa 1972, s. 120-146; H. Mayr-Harting, Two Conversions to Christianity. The Bulgarians and the Anglo-Saxons, w: idem, Religion and Society in the Medieval West, 600-1200, Aldershot 2010, s. 1-29; zob. też: I. Bilarsky, Word and Power in Medieval Bulgaria, Leiden-Boston 2011, s. 183-203; T. Stepanov, From "Steppe" to Christian Empire, and Back. Bulgaria between 800 and 1100, w: The Other Europe in the Middle Ages, s. 363-377; zob. też: T.C. Lounghis, Bulgaria instead of Moravia. Evidence of Major Political Changes, w: Byzantium, New Peoples. New Powers. The Byzantino-Slav Contact Zone from the Ninth to the Fifteenth Century, red. M. Kaimakamova, M. Salamon, M. Smorąg-Różycka, Kraków 2007 (Byzantina et Slavica Cracoviensia, 5), s. 63-70.

${ }^{29}$ P. Stephenson, Byzantium's Balkan Frontier. A Political Study of the Northern Balkans, 900-1204, Cambridge 2004, s. 18 nn.; J. Shepard, Slav Christianities, 800-1100, w: The Cambridge History of Christianity, t. 3: Early Medieval Christianities, c. $600-c .1000$, red. T.F.X. Noble, J.M.H. Smith, Cambridge 2008, s. 130-155; J.V.A. Fine, The Early Medieval Balkans. A Critical Survey from the Sixth to the Late Twelfth Century, Ann Arbor 1991, s. 132-158.

${ }^{30} \mathrm{~J}$. Bonarek, Przyczyny i cele bułgarskich wypraw Świętosława a polityka Bizancjum w latach sześćdziesiatych X wieku, SH 39, 1996, 3, s. 287-302; A. Poppe, Svjatoslav the Glorious and the Byzantine Empire, w: Byzantium, New Peoples, s. 133-138. 
Bazylego II Bułgarobójcy i klęska przeciwstawiających się mu wojsk cara Samuela w roku 1014 załamały państwowość bułgarską ${ }^{31}$. Cztery lata później, po śmierci wszystkich członków dynastii panującej, państwo całkowicie upadło, a całą Bułgarię włączono na niemal dwieście lat bezpośrednio do Cesarstwa Bizantyjskiego ${ }^{32}$.

Głęboki kryzys polityczny, z czasem i społeczny, przeżywała również - po okresie potęgi w X w. - w stuleciu XI państwowość ruska. Często zauważano w historiografii, że wczesna Ruś była tworem bardzo specyficznym. Znany amerykański badacz dziejów tego kraju, Richards Pipes $^{33}$, napisał o najdawniejszej Rusi, że jej organizacja w gruncie rzeczy przypominała bardziej kompanię handlową aniżeli inne ówczesne państwowości europejskie ${ }^{34}$. Uczony twierdził, iż w istocie trudno sobie wyobrazić jakiekolwiek inne państwo ówczesnej Europy, którego niemal cała elita przywódcza zjawiałaby się w jednym czasie i w jednym miejscu, by sprzedawać tam zgromadzone przez siebie towary. A tak było w przypadku Rusów, którzy regularnie odwiedzali Konstantynopol, zaopatrzeni głównie w futra i w niewolników ${ }^{35}$. Później zaś ludzie ci wracali na północ, by tam opłacać swoich kontrahentów tym, co kupili u Greków, zostawiając sobie - rzecz jasna - poważną część zysku. Pokojowy handel mógł szybko zmienić się w zwykły rozbój i rabunek, gdy partnerzy handlowi okazywali się mało spolegliwi, albo zaistniały jakieś inne okoliczności, które sprawiały, że Rusowie woleli używać mieczy zamiast wag i odważników ${ }^{36}$.

W ten zwięźle opisany sposób państwo ruskie miało funkcjonować ponad sto pięćdziesiąt lat. Mechanizm zaczął się jednak zacinać kilkanaście lat po przyjęciu chrześcijaństwa (988), zwłaszcza zaś po śmierci

31 P. Stephenson, The Legend of Basil the Bulgar Slayer, „Byzantine and Modern Greek Studies" 24, 2000, s. 102-132; idem, Byzantium's Balkan Frontier, s. 71 nn.

${ }^{32}$ G. Ostrogorski, Dzieje Bizancjum, Warszawa 1967 (oryg. niem. 1940), s. 250-252; J.V.A. Fine, op. cit., s. 197 nn.; D.P. Hupchick, The Bulgarian-Byzantine Wars for Early Medieval Balkan Hegemony. Silver-Lined Skulls and Blinded Armies, Cham 2017, s. 247 nn.; odrodzenie państwa w innych warunkach, również etnicznych nastąpiło u schyłku XII w. T. Wasilewski, Historia Bułgarii, Wrocław 1988 [1970], s. 78 nn.

${ }^{33}$ L.L. Gogle, Pipes, Richard, w: Encyclopedia of Historian and Historical Writing, t. 1, wyd. K. Boyd, London 1999, s. 922; zob. także: R. Pipes, Żyłem. Wspomnienia niezależnego, Warszawa 2004.

${ }^{34}$ R. Pipes, Rosja carów, Warszawa 2006 (oryg. ang. 1974), s. 31.

35 J. Martin, Treasure of the Land of Darkness. The Fur Trade and its Significance for Medieval Russia, Cambridge 1986, s. 35 nn.; J. Henning, Gefangenenfesseln im slawischen Siedlungsraum und der europäische Sklavenhandel im 6. bis 12. Jahrhundert, „Germania” 70, 1992, s. 403-426, s. 415 nn.; co ciekawe, fenomenu handlu elity ruskiej niewolnikami w zasadzie nie dostrzega: A. Rio, Slavery after Rome, 500-1100, Oxford 2017.

${ }^{36}$ W. Duczko, Ruś Wikingów. Historia obecności Skandynawów we wczesnośredniowiecznej Europie Wschodniej, Warszawa 2007, s. 73 nn. 
Włodzimierza Wielkiego (1015). Problemy ujawniały się w postaci sporów o władzę i miejsce w hierarchii pośród licznych synów księcia ${ }^{37}$. Do konfliktu wmieszał się władca polski Bolesław Chrobry, który popierał jednego z Rurykowiczów, swojego zięcia Świętopełka. W roku 1018 Bolesław pokonał wojska Jarosława Mądrego, który zdołał przechwycić po śmierci ojca tron kijowski. Następnie władca polski zdobył stolicę Rusi, a później wywiózł z niej znaczne łupy. Wiele przemawia za tym, że Bolesław chciał mieć w zięciu swego rodzaju namiestnika ${ }^{38}$. W ten sposób Ruś, a przynajmniej jej południowa część, zdegradowana zostałaby do roli prowincji państwa Bolesława Chrobrego. Władcy polskiemu zabrakło jednak sił na realizację śmiałych planów. $\mathrm{W}$ dodatku protegowany ambitnego Piasta, Świętopełk, nie godził się na tego rodzaju rozwiązanie ${ }^{39}$.

Rywalizację o tron kijowski wygrał Jarosław Mądry, który tuż po ustąpieniu z Rusi wojsk Bolesława Chrobrego zdołał wygnać Świętopełka z kraju. Po tym fakcie nie ma już wzmianek o tym, by teść przegranego w jakikolwiek sposób zareagował na to rozstrzygnięcie. W czasie tego zamieszania politycznego $\mathrm{w}$ dość niejasnych okolicznościach zginęli bracia przyrodni głównych oponentów, Borys i Gleb. Ich śmierć przypisano Świętopełkowi, tradycyjnie w dawnej ruskiej historiografii zwanemu „przeklętym”, jako temu, który związał się sojuszem z obcą potęgą w celu szkodzenia własnemu krajowi ${ }^{40}$.

Kryzys spowodowany trudnościami w wykreowaniu centralnej władzy w rozległej państwowości Rusi Kijowskiej, ujawniony w roku 1018, nigdy w istocie nie został trwale zażegnany. Co prawda nie ustała ekspansja terytorialna książąt i możnych ruskich na słabo zaludnione tereny fińskie (tzw. Ruś Zaleska) i pojawiali się też władcy, którzy swoją determinacją, przymiotami osobowości, a także dzięki łutowi szczęścia potrafili zdobyć prymat wśród rozrodzonych Rurykowiczów oraz wymusić uznanie swojego nadrzędnego autorytetu przez współrodowców, ale zawsze wraz z ich odejściem ustalony ład polityczny był niszczony i dochodziło do powtarzających się ustawicznych walk wewnętrznych ${ }^{41}$. Stabilizacja

${ }^{37}$ A. Poppe, Walka o spuściznę po Włodzimierzu Wielkim, KH 102, 1995, 3-4, s. 4-22.

38 Tak sprawę przedstawia Gall Anonim - Galli Anonymi Cronica et Gesta ducum sive principum polonorum, wyd. K. Maleczyński, Kraków 1952, s. 23 (1/7); zob. także: J. Banaszkiewicz, Bolesław i Predsława. Uwagi o uroczystości stanowienia władcy w zwiazku z wejściem Chrobrego do Kijowa, KH 97, 1990, 3/4, s. 3-35.

39 Повесть временных лет, wyd. Д.С. Лихачев, cz. 1, Москва-Ленинград 1950, s. 97.

40 Zob. nр.: Г.М. Филист, История „преступлений” Святополка Окаянного, Минск 1990.

${ }^{41}$ Ostatnio o kwestii walk wewnątrz dynastii panujących w regionie więcej: Z. Dalewski, Modele władzy dynastycznej w Europie Środkowo-Wschodniej we wcześniejszym 
i instytucjonalizacja władzy nigdy nie została na Rusi Kijowskiej osiągnięta aż do czasów późnego średniowiecza i pojawienia się organizmów zewnętrznych, uzależniających od siebie jej terytorium: Polski, a zwłaszcza Litwy oraz Moskwy ${ }^{42}$.

Nie sposób, rozpatrując problem postawiony w temacie niniejszego szkicu, nie spojrzeć na kryzys Węgier w połowie XI w. Wprawdzie elita tego kraju nie uległa wpływom słowiańskim w kwestii języka i stylu życia, ale przecież to państwo w zasadzie zawsze stanowiło integralną część naszego regionu Europy. Wszystko też przemawia za tym, że struktura polityczna stworzona przez koczowników węgierskich w Panonii była bardzo zbliżona do innych organizmów państwowych Środkowej Europy ${ }^{43}$. Podobnie jak w krajach sąsiednich, także na Węgrzech w XI w. kryzysy państwowości uzewnętrzniały się w walkach pomiędzy dynastami, wynikały również z braku instytucjonalnych regulacji kwestii następstwa tronu oraz nieustabilizowanego sposobu zaspokajania ambicji młodszych członków dynastii i innych, należących do jej bocznych linii ${ }^{44}$.

W X w. Węgrzy tworzyli federację plemienną, która stanowiła prawdziwe mocarstwo, zagrażające poważnie Niemcom i innym krajom zachodniej Europy. Klęska pod Augsburgiem na tzw. Lechowym Polu w 955 r. zatrzymała najazdy na Zachód, nie wpłynęła jednak na osłabienie mocnej pozycji Węgrów w regionie. Poważne problemy państwa ujawniły się dopiero po śmierci Stefana I Wielkiego w roku 1038. Król stracił syna przygotowywanego do zajęcia tronu, desygnował więc na

średniowieczu, Warszawa 2014; zob. także: J. Martin, Calculating Seniority and the Contests for Succession in Kievan Rus', „Russian History” 33, 2006, s. 267-281.

${ }^{42} \mathrm{~J}$. Pelenski, The Contest between Lithuania-Rus' and the Golden Horde in the Fourteenth Century for Supremacy over Eastern Europe, „Archivum Eurasiae Medii Aevi” 2, 1982, s. 300-320; О. Русина, Україна під татарами і Литвою, Київ 1998. Moskwie udało się przeforsować ideę (w którą wierzy się czasami również w Polsce), że to państwo jest jedynym pełnoprawnym sukcesorem Rusi Kijowskiej. Sukces ten w znacznej części związany był z udanym rozwinięciem bloku ideologii oznaczonych koncepcją Moskwy Trzeciego Rzymu, czy Świętej ziemi ruskiej - więcej o kwestii np.: M. Cherniavsky, „Holy Russia”. A Study in the History of an Idea, „The American Historical Review” 63, 1958, 3, s. 617-637; H. Paszkiewicz, Wzrost potęgi Moskwy, Kraków 2000; J.H. Billington, Ideologia moskiewska, w: Chrześcijaństwo Rusi Kijowskiej, Białorusi, Ukrainy i Rosji (X-XVII wiek), red. J. Kłoczowski, Kraków 1997, s. 173-217; szersze implikacje kwestii np.: A. Besançon, Święta Ruś, Warszawa 2012.

${ }^{43}$ L. Havlík, První slovanské státy (K charakteru vládnich struktur a počátkưm státnich formaci), „Slovanské historické studie” 10, 1974, s. 5-49; B. Krzemieńska, Hospodářské základy raně středověkého statú ve střední Evropě, „Hospodářské dějiny” 1978, s. 149-230.

${ }^{44}$ Z. Dalewski, op. cit., s. 243-246. 
swojego następcę siostrzeńca, Piotra Orseolo, pochodzącego z Wenecji. Ten nie był popularny na Węgrzech, szybko zatem został pozbawiony władzy. Uszedł do Niemiec, szukając tam wsparcia. Dostał je, ale musiał za nie zapłacić utratą tytułu królewskiego oraz uzależnieniem od Rzeszy ${ }^{45}$. Wyprawy niemieckie z lat 1041 i 1045 nie zapewniły jednak Piotrowi Orseolo trwałej władzy, ani nie ustabilizowały sytuacji. W 1046 r. w kraju wybuchł pogański bunt Vaty, lokalnego wielmoży ${ }^{46}$. Strukturę Kościoła odbudował przeciwnik i następca Piotra Orseolo, Andrzej I, pochodzący z młodszej linii Arpadów. Jednak i on w roku 1060 został pozbawiony władzy, tym razem przez brata, Belę I. Ten znów musiał walczył z kolejnym buntem pogańskim Vaty. Władza centralna na Węgrzech osiągnęła pewną stabilizację dopiero od czasów Władysława Świętego (1077-1095) ${ }^{47}$.

Rozpatrując ogólne problemy polityczne wczesnośredniowiecznej Europy Środkowej, badacze zwykle nie doceniają państw Słowian nadbałtyckich, zwłaszcza Związku Wieleckiego/Lucickiego ${ }^{48}$ oraz organizacji politycznych Obodrytów. Wydaje się, że przyczyną tego stanu rzeczy jest fakt późniejszego osłabienia i wreszcie upadku pozycji państwa obodrzyckiego oraz włączenia go do Rzeszy ${ }^{49}$, a także całkowitego zaniku państwa lucickiego. Te twory polityczne nie zdołały ponadto stworzyć wystarczająco silnych elit, które byłyby w stanie przetrwać upadek państwowości i przekazywać oraz upowszechniać pamięć o dokonaniach własnych społeczeństw. Pomimo zaś deklaracji obiektywizmu, powszechne jest konstruowanie obrazu przeszłości w oparciu o teraźniejszość, nawet przez tzw. profesjonalistów.

W interesującym nas czasie, patrząc z naszej perspektywy - krótkim, zarówno Wieleci/Lucice, jak i Obodryci odgrywali rolę podobną do „uznanych” w historiografii państwowości, np. czeskiej czy polskiej. Kluczowym dla organizacji politycznej Słowian zaodrzańskich faktem, który umożliwił im przejściową prosperitę, było zwycięstwo powstania

${ }^{45}$ G. Varga, Ungarn und das Reich vom 10. bis zum 13. Jahrhundert. Das Herrscherhaus der Árpáden zwischen Anlehnung und Emanzipation, München 2003, s. 112 nn.

${ }^{46}$ P. Engel, The Realm of St. Stephen. A History of Medieval Hungary, 895-1526, New York 2005, s. 45-48.

${ }^{47}$ G. Varga, op. cit., s. 145 nn.

${ }^{48}$ O fenomenie Związku Wieleckiego/Lucickiego ostatnio: Ch. Lübke, „Qui sint vel unde huc venerint”. Bemerkungen zur Herkunft der Namen von Polen und Liutizen, w: Die Suche nach den Ursprüngen. Von der Bedeutung des frühen Mittelalters, wyd. W. Pohl, Wien 2004 (Österreichische Akademie der Wissenschaften Philosophisch-Historische Klasse: Denkschriften, 322: Forschungen zur Geschichte des Mittelalters, 8), s. 279-288.

${ }^{49}$ F. Ruchhöft, Vom slawischen Stammesgebiet zur deutschen Vogtei. Die Entwicklung der Territorien in Ostholstein, Lauenburg, Mecklenburg und Vorpommern im Mittelalter Rahden/ Westfalen 2008 (Archäologie und Geschichte im Ostseeraum, t. 4), s. 155 nn. 
pogańskiego w roku $983^{50}$. W wyniku tego zdarzenia oraz innych jeszcze okoliczności, np. przesunięcia się osi zainteresowania politycznego Królestwa Niemieckiego/Cesarstwa Rzymskiego z Europy Środkowej na południe ${ }^{51}$, Słowianie nadbałtyccy na ponad wiek osiągnęli niezależność, przestrzeń do rozwoju i czas na ewentualną modernizację swoich struktur politycznych. Tę okazję potrafili - i to jedynie częściowo - wykorzystać tylko Obodryci ${ }^{52}$. W przeciwieństwie do swoich pobratymców ze wschodu, Wieletów/Luciców ${ }^{53}$, część Obodrytów wytworzyła względnie stabilną monarchię, której przywódcy - generalnie rzecz biorąc - nie przeciwstawiali się chrześcijaństwu, zdarzało się też, że sami byli chrześcijanami. Władcy Obodrytów nie zdołali jednak zdominować całego ludu i zawsze utrzymywała się u nich mniej lub bardziej liczna oligarchiczna federacja władztw. Zwykle też panujący, nawet gdy bywali chrześcijanami, respektowali utrzymanie się pogaństwa u części swoich poddanych.

Pomimo dość trudnego sąsiedztwa saskiego i duńskiego, zwłaszcza w XI w. do jego schyłku, Obodryci byli regionalną potęgą. Jednak relatywnie silni władcy: chrześcijanin Gotszalk (1043-1066), poganin Krut (10661090) nie potrafili wykorzystać pomyślnej koniunktury politycznej, by wzmocnić i unowocześnić organizację swojego państwa ${ }^{54}$. Każda zmiana władcy związana była z mniejszym lub większym kryzysem i walkami

50 W. Schich, Die ostelbische Kulturlandschaft des 10. und 12. Jahrhunderts im Vergleich, w: Polen und Deutschland vor 1000 Jahren. Die Berliner Tagung über den „Akt von Gnesen”, wyd. M. Borgolte, Berlin 2002 (Europa im Mittelalter 5), s. 61-89; J. Strzelczyk, Słowianie połabscy, Poznań 2002 (popularnie); Ch. Lübke, Powstanie i istota zwiazku Luciców. Jedna $z$ konsekwencji chrystianizacji Europy Wschodniej w X stuleciu, w: Chrześcijańskie korzenie. Misjonarze, święci, rycerze zakonni (eseje i szkice), red. S. Sterna-Wachowiak, Poznań 1997, s. 51-64; W.H. Fritze, Der slawische Aufstand von 983 - eine Schicksalwende in der Geschichte Mitteleuropas, w: Festschrift der landesgeschichtliche Vereinigung für die Mark Brandenburg zu ihrem hundertjährigen Bestehen, Berlin 1984, s. 9-55; W. Brüske, Untersuchungen zur Geschichte des Lutizenbundes, Münster, Köln 1955 (Mitteldeutsche Forschungen, 3), s. 39 nn.

${ }^{51} \mathrm{H}$. Keller, Zwischen regionaler Begrenzung und universalem Horizont. Deutschland im Imperium der Salier und Staufer 1024 bis 1250, Berlin 1986 (Propyläen-Geschichte Deutschlands, red. D. Groh, t. 2), s. 57 nn., 356 nn.; S. Weinfurter, Herrschaft und Reich der Salier. Grundlinien einer Umbruchzeit, Sigmaringen 1992; także: E. Boshof, Das Salierreich und der europäische Osten, w: Auslandsbeziehungen unter den salischen Kaiser, red. F. Staab, Speyer 1994, s. 167-192.

52 Więcej o kwestii: A. Turasiewicz, Dzieje polityczne Obodrzyców od IX wieku do utraty niepodległości w latach 1160-1164, Warszawa 2004; oraz: L. Leciejewicz, Główne problemy dziejów obodrzyckich, w: Słowiańszczyzna połabska między Niemcami a Polska, red. J. Strzelczyk, Poznań 1981, s. 167-182.

53 Zmiana nazwy ludu i jego związku politycznego nastąpiła po roku 983, tak jakby ci Słowianie chcieli zerwać z przeszłością i zapomnieć o swojej podległości monarchom Rzeszy, Ch. Lübke, „Qui sint vel unde huc venerint”, s. 148-150.

${ }^{54}$ J. Strzelczyk, Zapomniane narody Europy, Wrocław 2006, s. 229-271. 
wewnętrznymi, do których mieszali się Sasi i Duńczycy. Pomimo przejściowego opanowania na początku XI w. niemal całej późniejszej Meklemburgii i Pomorza Przedniego, władcy Obodrytów nie potrafili uzyskać dla siebie stabilnego i szerokiego wsparcia społecznego. Niezależnie od tego faktu, dynastom udało się przetrwać trwającą nawet kilka dziesięcioleci wojnę, toczoną wspólnie przez braci Przybysława i Niklota przeciwko połączonym armiom niemieckim i duńskim. Nawet gdy Niklot zginął w 1160 r. w bitwie z siłami Henryka Lwa i króla Danii Waldemara I Wielkiego ${ }^{55}$, to jego synowie zdołali zachować część władztwa obodrzyckiego za cenę uznania zwierzchności Saksonii. Dynastia obodrycka, z czasem zniemczona, panowała w Meklemburgii do $1918 \mathrm{r}^{56}$

Nie przetrwało natomiast XI w. w żadnej, najmniejszej nawet części władztwo Luciców. W przeciwieństwie do wcześniej wspominanych obodryckich pobratymców, Lucice mocno trzymali się pogaństwa i kultywowali specyficzną formę demokracji, której centrum znajdowało się w Radogoszczy, gdzie odbywały się wiece stanowiące najwyższą władzę Związku ${ }^{57}$. Jeszcze w połowie XI w. Lucice stanowili najmocniejszą militarnie i politycznie siłę na obszarze Połabia. Do osłabienia i w końcu upadku państwowości lucickiej przyczyniła się długotrwała wojna domowa, która wybuchła pod koniec 1056 r. o przywództwo w Związku. Dzięki niej zimą, na przełomie roku 1067 i 1068, biskupowi Burchardowi z Halberstadt udało się spustoszyć kraj Redarów (niegdyś głównego plemienia Luciców) i zdobyć oraz spalić Radogoszcz ${ }^{58}$.

Po tej swoistej desakralizacji centrum politycznego i ideowego Związku, wspólnota polityczna Luciców uległa dezintegracji i poszczególne plemiona nie mogły już oprzeć się atakom przeciwników. Te zaś stały się nasilone również dlatego, że Słowianie nadodrzańscy wciąż trzymali się pogaństwa. Tak więc tereny zajmowane przez Luciców były obiektem ustawicznych najazdów sąsiadów i w końcu zostały pomiędzy nich podzielone ${ }^{59}$.

${ }^{55}$ N. Rühberg, Niklot und der obodritische Unabhängigkeitskampf gegen das sächsische Herzogtum, „Mecklenburgische Jahrbücher” 111, 1996, s. 5-20.

${ }^{56}$ F. Wigger, Stammtafeln des Großherzoglichen Hauses von Meklenburg, ,Jahrbücher des Vereins für Mecklenburgische Geschichte und Altertumskunde" 50, 1885, s. 111-327.

57 R. Szczesiak, Auf der Suche nach Rethra! Ein interessantes Kapitel deutscher Forschungsgeschichte, w: Siedlung, Kommunikation und Wirtschaft im westslawischen Raum. Beiträge der Sektion zur slawischen Frühgeschichte des 5. Deutschen Archäologenkongresses, wyd. F. Biermann, Th. Kersting, Langenweißbach 2007, s. 313-334.

${ }^{58}$ R. Schmidt, Rethra. Das Heiligtum der Lutizen als Heiden-Metropole, w: Festschrift für Walter Schlesinger, t. 2, red. H. Beumann, Köln 1974, s. 366-394; albo: idem, Das historische Pommern. Personen, Orte, Ereignisse, Köln 2007, s. 73-100.

59 I. Fonnesberg-Schmidt, Papieże i krucjaty bałtyckie 1147-1254, Warszawa 2009 (oryg. ang. 2007), s. 33 nn. 
Spójrzmy teraz na ostatni, bardzo ważny przykład dla omawianego tu problemu - sprawę kryzysu państwowości wczesnopiastowskiej, jaki nastąpił w latach trzydziestych XI stulecia. Kwestia była już wielokrotnie analizowana i skąpe informacje źródeł są szeroko znane ${ }^{60}$, musimy tu jednak przedstawić pewien schemat wydarzeń, by zestawić go z przedstawionym wyżej materiałem dotyczącym innych państw z myślą budowania pewnych uogólnień. Należy tu też zaznaczyć, że dalecy jesteśmy przy tym od pewności, że problem został w pełni wyjaśniony, jeśli chodzi o jego przyczyny a nawet sam przebieg wydarzeń z nim związanych.

Niektóre źródła zawierają informacje o tym, że już u schyłku panowania Bolesława Chrobrego, około roku 1022, doszło w Polsce do jakichś zaburzeń społecznych ${ }^{61}$. Elita polityczna kraju jeszcze wtedy zdołała spacyfikować przeciwników. Znamienne, że w sytuacji niestabilności wewnętrznej, przejmujący władzę w roku 1025 Mieszko II zdecydował się na kontynuację polityki ojca. Związał się mianowicie w niemiecką opozycją wobec nowego króla, Konrada II, i zaatakował monarszych sprzymierzeńców w Saksonii. Początkowo wojna prowadzona była z sukcesami, udało się nawet w 1029 r. zatrzymać pod Budziszynem idącą na Polskę armię samego władcy. Dopiero później lepiej zorganizowana wyprawa Konrada II, skoordynowana przy tym $\mathrm{z}$ atakiem ruskim na Polskę, wspartym przez braci króla, doprowadziła w roku 1031 do klęski Mieszka II, który musiał uciekać z kraju. Władzę w Polsce przejął Bezprym, starszy brat wygnanego. Szybka jego śmierć umożliwiła Mieszkowi powrót, jeszcze w tym samym roku 1031. Jednak pozycja władcy była już słaba, dlatego musiał uznać się w roku 1032 za lennika Konrada II. Cesarz w dodatku wymógł na Mieszku, by ten przydzielił pewną część państwa Teodorykowi, swemu krewnemu (prawdopodobnie potomkowi jednego z synów Mieszka I i Ody); własną dzielnicę dostał też Otto, młodszy brat Mieszka II.

Zrozumienie tego, jak wyglądały dalsze losy dziedzictwa piastowskiego aż do roku 1039, nie jest łatwe wobec ubóstwa doniesień źródłowych. Wiemy zatem, że po śmierci swojego brata Ottona w roku 1033 Mieszko II zdołał ponownie zjednoczyć całość terytorium państwa, przeganiając Teodoryka, ale rok później zmarł. Później już sytuacja jest bardzo niejasna. Za kroniką tzw. Galla Anonima uważa się na ogół, że syn zmarłego, Kazimierz, zdołał przejąć tron po ojcu, ale wkrótce musiał uciekać z Polski, ponieważ doszło w kraju do masowego buntu ludności

${ }^{60}$ D. Borawska, op. cit.; H.J. Lang, op. cit.; G. Myśliwski, op. cit.; zob. także: B. Śliwiński, Bezprym. Pierworodny syn pierwszego króla Polski (986 - zima/wiosna 1032), Kraków 2014, s. $200 \mathrm{nn}$.

${ }^{61}$ D. Borawska, op. cit., s. 22 nn. 
przeciw władzy, połączonego z reakcją pogańską. Nie będziemy próbować stworzyć obrazu zmian w ówczesnej Polsce, ponieważ ustalenie nawet ogólnego ich przebiegu nie jest możliwe wobec skromności przekazów źródłowych. Na przytaczanie zaś przypuszczeń badaczy, dokumentowanych istniejącą literaturą, brak tu miejsca. W każdym razie przez jakiś czas (nawet, jak się czasami uważa, przez cztery lata) w Polsce nie istniała, jak się zdaje, żadna władza centralna ${ }^{62}$.

Korzystając z sytuacji, książę czeski Brzetysław najechał Wielkopolskę w roku $1038^{63}$, zniszczył i obrabował centrum państwa piastowskiego, być może starając się w ten sposób rozciągnąć swoją władzę przynajmniej nad centralnym terytorium konkurencyjnej dynastii, by w ten sposób uzależnić od siebie nawet cały kraj. Nie wiadomo, jaki byłby rozwój wypadków, gdyby nie reakcja Niemiec.

W roku 1039 Henryk III przydzielił Kazimierzowi Odnowicielowi wsparcie militarne w wyprawie do Polski w postaci 500 wojowników. Monarcha Rzeszy, jak się uważa, obawiał się zbytniego wzrostu siły Czech i groźnej dla niego sytuacji wykreowania silnego władztwa słowiańskiego, które mogłoby zagrozić dominacji niemieckiej w regionie ${ }^{64}$. Dysponujący poważnym wsparciem militarnym i politycznym Henryka III, syn Mieszka II zdołał opanować znaczną część ojcowizny. Rok później Czechy zostały zaatakowane przez wojska niemieckie, które powstrzymano z najwyższym trudem. Jednak już w latach 1041-1042 wyprawa kierowana osobiście przez Henryka III pokonała siły Brzetysława I ${ }^{65}$. Zaangażowanie księcia czeskiego w walkach obronnych przeciw Niemcom sprawiło, że musiał on zrezygnować ze znacznej części podbitych przez siebie ziem polskich i uznać prawa Kazimierza do całości schedy po ojcu.

W ten szkicowo opisany tu sposób państwo polskie, które w zasadzie całkowicie upadło po uciecze z kraju Kazimierza, zostało z powrotem powołane do życia. Tym razem, pomimo znanych perturbacji wiążących się z nieuporządkowaną kwestią sukcesji tronu, państwo piastowskie przetrwało już wiele stuleci.

62 Omówienie kwestii: ibidem, s. 147-191; zob. także: J. Bieniak, Państwo Miecława. Studium analityczne, Warszawa 1963, s. $87 \mathrm{nn}$.

63 Albo rok później, jak twierdzą niektórzy - zob.: M. Matla-Kozłowska, op. cit., s. $452 \mathrm{nn}$.

${ }^{64}$ B. Krzemieńska, Břetislav I. Čechy a střední Evropa v prvé polovině XI. století, Praha 1999.

65 Cosmae Pragensis Chronica Boemorum, wyd. B. Bretholz, Berlin 1923 (MGH SrG, Nova series t. 2) (II,12), s. 99; V. Novotný, České dějiny. I/2. Od Břetislava I. do Přemysla I., Praha 1913, s. 8 n.; B. Krzemieńska, Boj Knižete Bř́tislava I. o upevnění českého státu (1039-1041), Praha 1979 (Rozpravy Československé akademie věd 89/5), s. 55 n. 
Czas na pewne zestawienia, które pozwoliłyby nam uporządkować kwestię i próbować odpowiedzieć na pytania sformułowane na początku niniejszego szkicu. Przyjrzyjmy się zatem, patrząc na problem generalnie, jakie były podobieństwa głębokiego kryzysu, który wstrząsnął monarchią piastowską w latach 1034-1039, do wcześniej szkicowanych przypadków załamywania się władzy państwowej w środkowej i wschodniej Europie. Nie wahajmy się też zauważać różnic, jeśli informacje o nich pojawiały się w źródłach.

Zwróćmy zatem najpierw uwagę na to, że niemal we wszystkich cytowanych przypadkach kryzys, czy nawet upadek państwa, był poprzedzony okresem jego gwałtownego rozwoju terytorialnego i potęgi militarnej, często powiązanym z przyjęciem chrześcijaństwa przez wybitnego władcę. Pewna zbieżność pomiędzy konwersją a występującymi po niej, w perspektywie kilku dziesięcioleci, przypadkami załamania się państwowości każe spojrzeć ostrożniej na, przyjmowane często za dogmat, przekonanie, że chrześcijaństwo dawało niejako automatycznie dynastom wiele narzędzi do wzmocnienia i ugruntowania ich rządów. $\mathrm{Z}$ miejsca jednak odrzucamy pogląd, że utrzymanie osadzanych w kraju duchownych mogło być dla ludności dużym obciążeniem, dlatego dochodziło do buntów. Takich duchowych w X i na początku XI w. mogło być najwyżej kilkunastu.

Różnie wyglądał przedział czasu pomiędzy kulminacją siły państwa a okresem kryzysu: w Polsce był on stosunkowo krótki - niewiele mniej niż dwadzieścia lat (nie licząc pierwszych wiadomości o zaburzeniach społecznych w kraju z roku 1022) i tylko nieco więcej niż pół wieku po konwersji religijnej. Podobnie wyglądała sytuacja na Węgrzech, gdzie sukces chrystianizacji rozpoczyna rok 974 i przyjęcie chrztu przez księcia Gejzę, ojca św. Stefana, wraz z rodziną ${ }^{66}$, a okres walk wewnętrznych nastąpił zaledwie trzy lata po śmierci tegoż Stefana (1038). Kulminacją tych sporów były utrata niezależności przez Węgry (1044) i pogańskie bunty Vaty $(1046,1061)^{67}$.

Nieco słabiej zależność pomiędzy okresem potęgi, chrystianizacją kraju a następującym potem kryzysem władztwa widoczna jest w przypadku dziejów Wielkich Moraw. Tam dzieło skutecznej chrystianizacji kraju określać wypada najwcześniej na rok 963, a w zasadzie dopiero mniej więcej dwa dziesięciolecia później, gdy udało się zbudować

${ }^{66}$ Są świadectwa wcześniejszej akcji chrystianizacyjnej podejmowanej i z zachodu, z bawarskiej Passawy, i z Bizancjum, ale nie zakończyły się one sukcesem, F.R. Erkens, Pilgrim, Bischof von Passau, „Ostbairische Grenzmarken” 34, 1992, s. 25-37.

67 P. Engel, op. cit., s. 45-47. 
podstawową organizację lokalnego Kościoła. Jednak zaledwie kilka lat po śmierci Świętopełka I, około roku 900, nastąpił upadek państwa wraz z wymarciem dynastii. We wczesnośredniowiecznych Czechach odnajdujemy podobną zależność. Kraj nominalnie chrystianizowany był już od mniej więcej połowy IX w., ale biskupstwo praskie zaistniało najwcześniej w roku $973^{68}$. Wtedy też dynaści czescy kontrolowali nie tylko obszar Czech, części Moraw, ale i południe Polski. Pod koniec tego stulecia spotkały Przemyślidów klęski w kolejnych wojnach, zaś niespełna trzydzieści lat później (w latach 1002-1004) los dynastii zawisł na włosku, gdy Bolesław Chrobry przejął rządy w Pradze.

Przypomnijmy tu jeszcze przykład pierwszego państwa serbskiego i księcia Mutimira, ewangelizatora kraju i twórcy jego przejściowej potęgi. Zmarł w roku 892, a w 950, po dziesięcioleciach walk wewnętrznych i zmieniających się, raczej słabych, władców, ostatni panujący z rodu Wyszesławiców, Czasław Klonimirović, zginął z rąk Węgrów, a wraz z jego śmiercią zanikło państwo.

Proces upadku najstarszego państwa bułgarskiego był bardziej złożony. Po śmierci w 927 r., wybitnego władcy Symeona, który schrystianizował kraj, państwo przetrwało niemal wiek, ale jego władcy nie potrafili stworzyć siły na tyle potężnej, by sprostać Bizancjum i ostatecznie państwo upadało w roku 1018, wraz z zanikiem dynastii.

$\mathrm{Na}$ koniec tego zestawienia zauważmy jeszcze, że szkicowany tu ogólny schemat kryzysu państwowości - i następstwo kryzysu po okresie potęgi - sprawdza się nawet w sytuacji pogańskiego Związku Lucickiego. Wspomniana organizacja polityczna przed wojną domową z drugiej połowy XI w. dominowała na wielkich obszarach Zaodrza, budząc respekt zarówno u swoich słowiańskich, jak również niesłowiańskich sąsiadów. W roku 1056 współdziałające jeszcze ze sobą plemiona lucickie z powodzeniem przeciwstawiły się najazdowi, rozbijając pod Przęcławą (Hawelbergiem/Hobolinem) silną armię niemiecką dowodzoną przez Wilhelma, margrabiego Marchii Północnej ${ }^{69}$. W ich przypadku to zapewne brak instytucji monarchii sprawiał, że poszerzenie strefy wpływów politycznych nie zostało zarejestrowane przez kronikarzy jako formalne powiększenie terytorium państwa, ponieważ - przyzwyczajeni do opisywania sfery wpływów władcy - kronikarze nie byli w stanie dostrzec faktu poszerzenia obszaru dominacji ludu.

${ }^{68}$ Data w istocie dość niepewna, a pierwszy ordynariusz praski mógł zagościć w swojej stolicy najwcześniej w roku 976, G. Zimmermann, Wolfgang von Regensburg und die Gründung des Bistums Prag, w: Tausend Jahre Bistum Prag 973-1973. Beiträge zum Millenium, wyd. E. Kumzmann, A. Nittner, München 1974, s. 70-92.

${ }^{69}$ W. Brüske, op. cit., s. 75 nn. 
Jednak i w sytuacji Związku Lucickiego, tak samo jak i w innych przywołanych tu przypadkach, zewnętrzną (lub zauważalną) oznaką kryzysu były walki o władzę wewnątrz organizacji politycznej. Za Odrą zmagania prowadzone były przez plemiona, a w zasadzie oligarchie plemienne, gdzie indziej w szranki stawali członkowie dynastii. Zawsze też, co poniekąd oczywiste, do walk wewnętrznych włączały się, często zapraszane przez zwaśnione strony, siły ościenne. Wykorzystywały one sytuację, co było nagminne, do forsowania swoich zamierzeń względem osłabionego wojną domową kraju, rozciągając nad nim swoją zwierzchność, czasami zaś go podbijając. Interwencja zewnętrzna w ogarniętym zamętem państwie jeśli nie miała na celu jego zniszczenia - prowadziła z kolei do pewnej stabilizacji i wzmocnienia władzy centralnej. Ceną oczywiście była zależność od dobroczyńcy, ale ta po jakimś czasie była kontestowana i miejscowe elity pragnęły odzyskać pozycję utraconą w wyniku kryzysu i obcej interwencji. Dążenia te z kolei spotykały się z nieprzychylną reakcją ze strony niedawnego dobrodzieja, zainteresowanego funkcjonowaniem uzależnionego od siebie państwa, ale bynajmniej nie jego siłą, która mogłaby zagrozić istniejącemu i pożądanemu przez państwo dominujące status quo. Dla ilustracji tej sytuacji możemy wskazać przykład Czech, gdzie pomoc Henryka II doprowadziła do restytucji władzy Przemyślidów. Gdy ci jednak niespełna cztery dekady później, wzmocnieni wewnętrznie, chcieli wykorzystać upadek władzy piastowskiej i przejąć przynajmniej część terytorium zajmowanego przez konkurencyjną dynastię, Przemyślidę Brzetysława I spotkała reprymenda ze strony Henryka III. Elita polityczna Rzeszy w XI w. uprawiała zatem grę polityczną, której celem było utrzymanie pewnej równowagi sił pomiędzy państwami chrześcijańskimi w szerokiej przestrzeni Europy Środkowej. Zadanie to było tym trudniejsze, że już chociażby wspomniane we wcześniejszej części niniejszych rozważań przykłady pokazują, iż państwa regionu były instytucjonalnie niestabilne. Warto jednak zauważyć, że istnienie dynastii - pomimo zdarzających się nagminnie walk w jej łonie - było podstawą odradzania się państwowości po okresie zamętu i załamania się władzy centralnej. Znaczenie rodu dynastycznego w tej sytuacji było więc ambiwalentne, bo przecież walki w jego obrębie destabilizowały państwo. Jednak bez własnej dynastii elity polityczne pogrążonego w kryzysie, zdestabilizowanego społeczeństwa nie były w stanie odtworzyć państwa. Widać to wyraźnie na szkicowanych tu przykładach Bułgarii czy Serbii, które wyraźnie pokazują, że społeczności pozbawione dynastii skazane były na utracenie swoich państwowości ${ }^{70}$.

70 Wprawdzie w Carstwie Bułgarii dynastia (wywodząca się od chana Kruma) wymarła prawie pół wieku przed zanikiem państwa, w roku 971, ale Samuel Komitopul 
Istniej wiele świadectw potwierdzających, że znaczenie dynastii jako czynnika integrującego społeczność, nawet w sytuacji walk pomiędzy jej członkami, polegało na przypisywaniu jej znaczenia sakralnego ${ }^{71}$. Zabicie jedynego żyjącego członka rodziny panującej wiązało się zatem z tak silną dezintegracją ideową ludu, że często ów fakt kończył istnienie państwa. Podobny charakter miało zniszczenie sanktuarium pogańskiego w Radogoszczy - swego rodzaju świętej stolicy, ideowego centrum społeczności, którego implikacją był upadek Związku Lucickiego. Jednak oligarchiczna republika Słowian nadbałtyckich $\mathrm{z}$ racji swojego ustroju stanowiła unikat. Typową formą organizacji państwowej w Środkowej Europie była monarchia ${ }^{72}$. Pozostając zatem przy powszechnie występującym modelu rządów, spróbujmy się zastanowić, co jeszcze - prócz wskazanej już wyżej kwestii braku ustalonego, akceptowanego i przestrzeganego przez szersze elity sposobu sukcesji władzy - przyczyniało się do kryzysów trapiących państwa środkowoeuropejskie w X i w pierwszej połowie XI w.

Nie sposób jednak, nawet w tak zwięzłym szkicu, próbować analizować kwestię bez zastanowienia się, przynajmniej pobieżnego, jaki był charakter omawianych tu organizacji politycznych, bo przecież zanim rozważy się problem kryzysu państwa, trzeba wiedzieć, czym państwo środkowoeuropejskie w okresie wczesnego średniowiecza było.

Sprawa nie jest oczywiście prosta - jest wiele kontrowersji wśród badaczy, i to nie tylko wiążących się z rozumieniem zagadnień szczegółowych, ale też dotyczących spraw zasadniczych. Stoi za tym wszystkim, co typowe, jeśli chodzi o region i epokę, ubóstwo źródeł i niejednoznaczność ich treści.

Jednak, zarówno gdy czytamy przekazy o najstarszym państwie słowiańskim tzw. Samona, jak i też młodszych, np. wielkomorawskim czy także wczesnopiastowskim, zwraca uwage pewien szczególny fakt. Otóż ważniejsi niż sprawa terytorium, na którym sytuowała się władza, byli ludzie tę władzę konstytuujący. Chodzi mianowicie o władcę i jego bliższe, ale również dalsze otoczenie, stanowiące wówczas nie tylko swego rodzaju administrację kraju, ale i jego armię. Ten zasadniczy składnik

(976-1014), który zdołał przechwycić wówczas władzę, pochodził z arystokracji zbliżonej do carskiej rodziny i zastąpił swoimi sukcesami pamięć o wymarłej dynastii, T. Wasilewski, Historia Bułgarii, s. 220-229; J.V.A. Fine, op. cit., s. 188-200.

${ }^{71}$ G. Dux, Die Genese der Sakralität von Herrschaft. Zur Struktur religiösen Weltverständnisses, w: Das frühmittelalterliche Königtum, wyd. F.-R. Erkens, Berlin-New York 2005, s. 9-21; H.A. Myers, H. Wolfram, Medieval Kingship, Chicago 1982.

${ }^{72}$ Również większość księstw regionu de facto była monarchiami, bo organizowały one odrębne etnosy i pełnia władzy w ich obrębie należała nominalnie do jednego człowieka, M. Szczaniecki, Powszechna historia państwa i prawa, Warszawa 1994, s. 48 nn. 
wczesnego państwa zwany był w świecie słowiańskim drużyną (od słowa drug/druh), gdyż ludzie wchodzący w skład tej instytucji uważani byli za swojego rodzaju „przyjaciół” władcy. Członkowie książęcej drużyny nie posiadali żadnych dóbr ziemskich a podstawą ich utrzymania były daniny uzależnionej ludności rolniczej oraz łupy czy produkty uzyskiwane za pośrednictwem handlu przyznawane im przez władzę państwową. Czasami panujący bądź jego zarządcy wprost kierowali drużynników do określonych lokalnych wspólnot terytorialnych, by one utrzymywały ich przez jakichś $\mathrm{czas}^{73}$. W istocie zatem podstawowa struktura wczesnego państwa - utworzona jeszcze na długo przed tzw. czasami historycznymi - polegała w dużym uproszczeniu na tym, że istniała pewna dychotomia $^{74}$. Po jednej stronie występowali mobilni ludzie władzy - wojownicy, nieposiadający na własność żadnej nieruchomości i osobistych stałych dochodów, po drugiej zaś byli użytkownicy ziemi - rolnicy, członkowie eksploatowanych przez władzę wspólnot terytorialnych ${ }^{75}$. Ponieważ z oczywistych powodów ten system był niestabilny, już bardzo wcześnie na tzw. plemiennym etapie formowania się państwa władza budowała miejsca umocnione - grody, które były dla niej schronieniem, fizycznym znakiem panowania, a prócz tego wypełniały inne różnorakie zadania ${ }^{76}$.

${ }^{73} \mathrm{Na}$ Rusi tego rodzaju zwyczaj nazywano „kormlenie” (karmienie), jeśli dodatkowo drużynnicy przemierzali kraj i zbierali daniny (często na zasadzie rozboju) określano ów fakt jako „poljudie”, А.Е. Пресняков, Княжое право в древней Руси. Очерки по истории Х-ХІІ столетий. Лекциии по русской истории, Киевская Русь, Москва 1993, s. 405 nn.; do „kormlenia” podobny jest zwyczaj opisany w kronice tzw. Fredegara, polegający na narzuceniu podobno Słowianom obowiązku utrzymywania w swoich domach wojowników awarskich, Chronicarum que dicuntur Fredegarii scholastici, wyd. B. Krusch, MGH SS 2, Hannoverae 1888, s. 118-193, 144 (c. 48); G. Labuda, Pierwsze państwo słowiańskie. Państwo Samona, Wodzisław Śląski 2009, s. 267; zob. także: F. Curta, Slavs in Fredegar and Paul the Deacon. Medieval gens or „Scourge of God”?, „Early Medieval Europe” 6, 1997, 2, s. 141-167.

${ }^{74}$ Jeśli będziemy zgłębiać problem, dostrzeżemy, iż w istocie ten podstawowy dwudzielny schemat zyskiwał pewną przestrzenność, ponieważ część ludzi władzy pochodziła z oligarchii plemiennej osadzonej na ziemi i posiadającej własność. Generalnie jednak ten fakt nie rozbija uczynionej wyżej systematyzacji, ponieważ nie był dominujący.

${ }^{75}$ F. Curta, Horsemen in Forts or Peasants in Villages? Remarks on the Archeology of Warfare to the 6th to the 7th c. Balkans, w: War and Warfare in Late Atiquity, wyd. A. Sarantis, Leiden-Boston 2013, s. 809-850.

${ }^{76}$ Z. Kurnatowska, Grody wielkopolskie jako źródło do poznania wczesnego średniowiecza, „Wielkopolskie Sprawozdania Archeologiczne” 6, 2003, s. 10-14; M. Kara, Najstarsze państwo Piastów - rezultat przełomu czy kontynuacji? Studium archeologiczne, Poznań 2009, s. 203 nn.; A. Buko, Archeologia Polski wczesnośredniowiecznej. Odkrycia - hipotezy - interpretacje, Warszawa 2005, s. 208 nn.; także: idem, Unknown Revolution. Archaeology and the Beginnings of the Polish State, w: East Central and Eastern Europe in the Early Middle Ages, red. F. Curta, Ann Arbor 2005, s. 162-178. 
Jednak wciąż warunkiem trwania państwa było nieme przyzwolenie rolników na eksploatację, bardzo nieraz dowolnie przeprowadzaną, oraz zadowolenie z panującego porządku wojowników - podstawy ówczesnego państwa.

Ludziom należącym do sił zbrojnych kraju i jednocześnie jego, dość swoistej, administracji nie mogły wystarczyć podstawowe warunki egzystencji, wymagali oni od władzy dostarczania przedmiotów i materiałów luksusowych, które miały podkreślać i uzewnętrzniać ich wysoki status i elitarną pozycję - „przyjaciół” czy nawet „krewniaków” panującego. Tego rodzaju potrzeby, w sytuacji ubóstwa i prostoty lokalnej wytwórczości oraz obecności obcych kupców, dostarczających znakomite towary zachodnioeuropejskie, a zwłaszcza bizantyjskie i arabskie, sprawiały, że poważnym motorem napędzającym procesy państwowotwórcze w Europie Środkowej był handel dalekosiężny ${ }^{77}$. W zamian za luksusowe towary elity w regionie nie mogły oferować wytwórczości rzemieślniczej swoich poddanych, a jedynie najcenniejsze wytwory miejscowej natury: skóry zwierząt futerkowych, a zwłaszcza niewolników ${ }^{78}$.

Jeśli więc wrócimy do cytowanych już tu słów Pipesa na temat państwa staroruskiego, że było w istocie swego rodzaju kompanią handlową, zorganizowaną w celu eksportu niewolników i futer do Bizancjum i do krajów arabskich oraz redystrybucji towarów wyżej cywilizowanych regionów, to w istocie ta uwaga - choć zdaniem autora miała ona dotyczyć tylko Rusi - z powodzeniem może być zastosowana do wszystkich wczesnych państw regionu ${ }^{79}$. Były one tworami bardzo słabo zakorzenionymi w społeczeństwie, a działalność ich elit sprowadzała się do doraźnego objazdu luźno kontrolowanych obszarów, zbierania danin, opłat za rozstrzyganie sporów, karania opornych, pacyfikacji przeciwników i nagradzania swoich ludzi oraz sprzymierzeńców w uzależnionych prowincjach darami w postaci importowanych towarów luksusowych ${ }^{80}$.

77 P. Urbańczyk, Władza i polityka we wczesnym średniowieczu, Wrocław 2000, s. 212.

78 Z. Kowalska, Handel niewolnikami prowadzony przez Żydów w IX-XI wieku w Europie, $\mathrm{w}$ : Niewolnictwo i niewolnicy $w$ Europie od starożytności po czasy nowożytne, red. D. Quirini-Popławska, Kraków 1998, s. 81-91.

${ }^{79}$ Handel niewolnikami przysparzał poważnych dochodów nawet elicie państwa wschodniofrankijskiego i państwa dynastii ottońskiej, H. Mayr-Harting, The Church of Magdeburg. Its trade and its town in the tenth and early eleventh centuries, w: Church and city 1000-1500. Essays in Honour of Christopher Brooke, red. D. Abulatia, M. Franklin, M. Rubin, Cambrigde 1992, s. 129-150; zob. także: J. Henning, op. cit., s. 403-426; W. Korta, Problem niewolnictwa $w$ Polsce wczesnośredniowiecznej, w: Społeczeństwo Polski średniowiecznej. Zbiór studiów, t. 2, red. S.K. Kuczyński, Warszawa 1982, s. 82-124, 95 nn.

${ }^{80} \mathrm{Z}$ takiego charakteru ówczesnego państwa wynikają problemy archeologów z odkryciem śladów obecności Wielkich Moraw czy wczesnego państwa Przemyślidów 
Ten, w wielkim uproszczeniu naszkicowany system funkcjonowania ówczesnego państwa, by mógł działać sprawnie, wymagał współistnienia jednocześnie wielu czynników - wśród nich najważniejsze były: względny dostatek żywności ${ }^{81}$, sukcesy wojskowe władcy i generalne zadowolenie z niego elit politycznych. Wystarczyło, żeby któryś z ważnych aspektów życia społecznego doświadczył jakichś trudności, a cały mechanizm państwowy znajdował się na progu katastrofy ${ }^{82}$.

Wiemy, że słabo rozwinięte rolnictwo dostarczało tylko minimalnych nadwyżek żywności, które mogliby przechwycić ludzie książęcy ${ }^{83}$, dlatego w zasadzie zawsze, aż do pojawienia się osadników zachodnioeuropejskich i wraz z nimi regularnej trójpolówki, zapewniającej relatywnie stabilne i wysokie plony, poważnym zajęciem elit przywódczych państw regionu było wzajemne podkradanie sobie bydła oraz ludzi ${ }^{84}$. Bydło było niezbędne do utrzymania żyzności ziemi w systemie prymitywnej, nieregularnej dwupolówki ${ }^{85}$. Jeśli chodzi zaś o ludzi - rolników, to im większa był ich liczba, tym (przy względnie dużej powierzchni wolnych do zagospodarowania ziem) większe daniny i więcej żywności można było od nich zebrać.

Kwestia ta była kluczowa dla funkcjonowania systemu społecznego, bo przecież jeśli następowało nawet drobne zachwianie warunków pogodowych, czy też pojawił się inny czynnik pogarszający plony, to dochodziło do głodu, często masowego. Miały wtedy miejsce, co poniekąd oczywiste, bunty i rozruchy wśród społeczności rolników, co pośrednio wpływało również na postawy elit względem monarchy ${ }^{86}$. W wyższych

(obecności dokumentowanej jedynie źródłami pisanymi) na południu dzisiejszej Polski, P. Urbańczyk, Early State Formation in East Central Europe, w: East Central and Eastern Europe in the Early Middle Ages, s. 139-151; zob. także: J. Macháček, Disputes over Great Moravia. Chiefdom or state? The Morava or the Tisza River?, „Early Medieval Europe” 17, 2009, 3, s. $248-267$.

${ }^{81}$ Każda legenda dynastyczna, ideologia władzy podkreślała możliwości panującego zapewnienia jego ludziom dostatku żywności, J. Banaszkiewicz, Podania o „Poczatku”, w: Dynastie Europy, red. A. Mączak, Wrocław 1997, s. 17-45.

82 J. Adamus, Problemy absolutyzmu piastowskiego, „Czasopismo Prawno-Historyczne" 10, 1958, 2, s. 19-76; P. Urbańczyk, Władza i polityka, s. 65 nn.

${ }^{83}$ Z. Kurnatowska, Uwagi na temat agrotechniki Słowian, „Prace i Materiały Muzeum Archeologicznego i Etnograficznego w Łodzi. Seria archeologiczna” 25, 1978, s. 221-229.

${ }^{84}$ W. Korta, op. cit., s. $92 \mathrm{nn}$.

${ }^{85}$ Często trybut był płacony właśnie w bydle - według Kosmasa od czasów Karola Wielkiego Czesi mieli oddawać Frankom corocznie 120 wołów - Cosmae Pragensis Chronica, s. 93 n. (II, 8); zob. także: Z. Kurnatowski, Studia osadnicze nad struktura zasiedlenia i gospodarka, w: Ziemie polskie w X wieku, s. 329-349.

${ }^{86}$ W Skandynawii w okresie wczesnego średniowiecza zabijano lokalnych królów, jeśli powtarzały się lata nieurodzaju, H.A. Myers, H. Wolfram, op. cit., s. 236. 
kręgach społeczeństwa mogło też rodzić się niezadowolenie, jeśli panujący nie był w stanie zapewnić swoim ludziom życia na odpowiednio wysokim poziomie i nie wywiązywał się ze zwyczajowego obowiązku ich regularnego obdarowywania dobrami luksusowymi sprowadzanymi z zewnątrz. Niezadowolenie było, co oczywiste, nostalgią za epoką wcześniejszą $\mathrm{w}$ dziejach państwa - czasami pogańskimi - i pojawiały się pogłoski, że za niepowodzenia odpowiedzialna jest nowa religia.

Jeśli teraz, pamiętając o powyższych kwestiach, przyjrzymy się poszczególnym przypadkom kryzysu państw środkowoeuropejskich i bałkańskich, to możemy dostrzec, iż za ich wystąpieniem stały pewne splatające się ze sobą okoliczności. Otóż, powtórzmy, zawsze kryzys był poprzedzony okresem długotrwałej wojny. Nawet jeśli finał tych zmagań militarnych - jak na przykład w sytuacji państwa Bolesława Chrobrego - był korzystny dla władzy, to jednak zawsze doprowadzały one do spadku liczebności ludności rolniczej i przetrzebienia stad bydła ${ }^{87}$. Strat tych nie były w stanie wyrównać rabunki ludzi i bydła dokonywane na terenach krajów ościennych. W efekcie obszar ziem uprawnych się kurczył, a istniejące pola - nienawożone z braku zwierząt, które mogłyby się na nich paść - z czasem ulegały wyjałowieniu, wysokość plonów spadała i pojawiał się głód ${ }^{88}$.

Łupy były dla militarnych elit państwa istotnym źródłem pozyskiwania przedmiotów luksusowych, ale paradoksalnie zbyt długi okres trwania wojny, zwłaszcza z silnym przeciwnikiem ${ }^{89}$, utrudniał władcy stałe zaopatrywanie swoich ludzi w zbytkowne przedmioty, których posiadanie podkreślało ich wysoki status społeczny i przewagę nad innymi oraz wiązało tych ludzi z panującym ${ }^{90}$.

${ }^{87}$ Badania archeozoologiczne wskazują następującą zależność: w okresie pokoju zwiększała się liczba hodowanych krów, spadała w czasach wojen na korzyść świń, D. Makowiecki, Hodowla oraz użytkowanie zwierzą na Ostrowie Lednickim w średniowieczu. Studium archeozoologiczne, Poznań-Lednogóra 2001; zob. także: Pradzieje Wielkopolski. Od epoki kamienia po średniowiecza, red. M. Kobusiewicz, Poznań 2008, s. 299 nn.; T. Kozłowski, Stan biologiczny i warunki życia ludności „in Culminie” na Pomorzu Nadwiślańskim (X-XIII wiek). Studium antropologiczne, Torun 2012.

${ }^{88}$ K. Tobolski, Środowisko przyrodnicze Europy Środkowej w czasach św. Wojciecha, w: Chrześcijańskie korzenie. Misjonarze, święci, rycerze zakonni (eseje i szkice), red. S. Sterna-Wachowiak, Poznań 1997, s. 87-92.

${ }^{89}$ Wtedy jeńców nie było wielu, kupcy unikali obszarów objętych długą, zażartą wojną, a przecież czyny wojenne trzeba było sowicie nagradzać.

90 Omówienie różnych społecznych funkcji wymiany darów (wprawdzie w zasadzie bez uwzględniania dawnej Europy, ale z wymienieniem zasad i w niej obowiązujących) w klasycznej pracy: M. Mauss, Szkic o darze. Forma i podstawy wymiany w społeczeństwach archaicznych, w: idem, Socjologia i antropologia, Warszawa 1973 (oryg. franc. 1968), 
Te dwa tylko czynniki - stale występujące w większości analizowanych tu przypadków kryzysów państw - wystarczały, by mocno podkopać zaufanie elit do panującego systemu. Wiemy jednak doskonale, że ludzie są $\mathrm{w}$ stanie wiele znieść i wiele dać z siebie, jeśli natchnieni są przez jakieś idee. W czasie nas interesującym trudno przypuszczać, by elita panująca w państwach regionu miała inną trwałą bazę ideową prócz wiary w dynastię, jeśli ta okazywała się skuteczna i zapewniała swoim ludziom sukcesy. Stara wiara pogańska uległa przecież erozji, nowa nie miała wystarczająco dużo czasu, by się zakorzenić. Istniało zresztą wiele sprzeczności pomiędzy założeniami chrześcijaństwa a praktykami władzy powszechnymi w interesującym nas czasie i miejscu. Elity przywódcze w państwach centralnej i wschodniej Europy nawet jeszcze w końcu X i w XI w. czerpały przecież znaczne dochody z handlu niewolnikami. Żywym towarem płacono m.in. za arabski kruszec, bizantyjskie jedwabie czy frankijskie miecze - towary chętnie przyjmowane przez drużynników. $W$ interesującym nas czasie jednak, wraz z chrystianizacją kurczył się teren, z którego można było pozyskiwać brańców i sprzedawać ich w niewolę Żydom, którzy w zasadzie zmonopolizowali handel niewolnikami do krajów arabskich ${ }^{91}$. Wywozu chrześcijan poza obszary kontrolowane przez Kościół zabraniali zaś biskupi ${ }^{92}$. Chodziło tu nie tylko o utratę wiernych, ale i sprzeciw hierarchów wobec nagminnych praktyk kastrowania chłopców, bo rzezańcy cieszyli się wielkim popytem nie tylko na arabskich targach niewolników, ale również bizantyjskich ${ }^{93}$.

Wskazane wyżej, splatające przeważnie się ze sobą okoliczności sprawiały, że gwałtownie dotychczas rozwijające się organizmy państwowe napotykały liczne bariery. Prócz tych już tu wspomnianych, można jeszcze dodać kłopoty logistyczne w postaci małych możliwości kontrolowania rozległych obszarów, których potrzebowały wczesne państwa z racji ekstensywnego, rabunkowego sposobu eksploatacji podbitych społeczności ${ }^{94}$. Gdy trudności ulegały spiętrzeniu, te agresywne, ale w gruncie rzeczy słabe instytucjonalnie twory polityczne ulegały załamaniu. By przetrwać, kryzys musiały być reanimowane poprzez pomoc zewnętrzną

s. 107-168; zob. także: D. Adamczyk, Silber und Macht. Fernhandel, Tribute und die piastische Herrschaftsbildung in nordosteuropäischer Perspektive (800-1100), Wiesbaden 2014.

${ }^{91}$ Z. Kowalska, op. cit., s. 81-92.

92 W. Korta, op. cit., s. 93 n.; P. Urbańczyk, Władza i polityka, s. 212.

93 A. Grabowski, Eunuch between Economy and Philology. The Case of „carzimasium”, „Mélanges de l'École française de Rome - Moyen Âge” 127.1, 2015 - https://mefrm. revues.org/2408 (dostęp: 1 XII 2017).

${ }_{94}$ P. Urbańczyk, Władza i polityka, s. 71. 
ze strony silniejszych państw, jeśli rzecz jasna tego rodzaju wsparcie było dla potencjalnego dobrodzieja politycznie korzystne (Czechy, Polska, Węgry).

Czasami państwo odradzało się samoistnie (Bułgaria, Serbia w XII w.), ale zawsze wtedy potrzebna była idea, chociażby w postaci pamięci o dokonaniach przodków. Wiele też znaczyło dla odbudowy państwa posiadanie ugruntowanej organizacji kościelnej. Warunkiem niezbędnym do dalszej egzystencji każdej powołanej z powrotem do życia organizacji politycznej była jednakże przebudowa systemu funkcjonowania państwa i naśladowanie oraz adaptacja rozwiązań stosowanych w społeczeństwach wyżej w tej kwestii rozwiniętych. Słowianie bałkańscy, co przecież naturalne, byli poddani sile oddziaływania wzorców bizantyjskich ${ }^{95}$. Polacy, Czesi, częściowo także Węgrzy z pewnością podpatrywali sposoby budowania władzy stosowane przez dynastów niemieckich na uzależnianych od nich obszarach zachodnio-słowiańskich. Tym bardziej przykłady administracji ottońskiej i dynastów salickich oddziaływały na wschodnich sąsiadów Rzeszy, że one same nie mogły być im zupełnie obce, bowiem stanowiły hybrydę systemu funkcjonowania dawnego państwa wschodnio-frankijskiego oraz rozwiązań stosowanych w organizacjach plemiennych istniejących wśród Słowian na Łużycach czy na terenie dzisiejszej Austrii ${ }^{96}$.

Sprawy ustroju wczesnych państw słowiańskich są niejasne i przez to sporne, ale jednego można być pewnym. Nie da się zamknąć kwestii prostym stwierdzeniem naśladownictwa, importu gotowych rozwiązań. Z pewnością zawsze, jeśli sytuacja wymuszała tego rodzaju działanie, adaptowano do miejscowych realiów mechanizmy poznawane gdzie indziej i uznawane za dobre dla władzy. Wydaje się, że takie mogły być początki tzw. organizacji służebnej, znanej w państwach zachodniosłowiańskich (Polska, Czechy) i na Węgrzech ${ }^{97}$, ale niewystępującej ani na Rusi, ani na Bałkanach. Kwestia oczywiście wymaga weryfikacji, pogłębionych badań. Jednak już chociażby istnienie tego systemu aprowizacji ludzi książęcych

${ }_{95}$ Podobnie zresztą Węgrzy - G. Moravcsik, Byzantium and the Magyars, Budapest 1970, s. 37 nn.

${ }^{96} \mathrm{Ch}$. Frey, The Burgward Organisation in the Eastern Marches of the German Realm, w: Château Gaillard 26. Études de castellologie médiévale. Château et frontière. Actes du colloque international d'Aabenraa (Danemark, 24-31 août 2012), red. P. Ettel, A.-M. Flambard Héricher, K. O'Conor, Caen 2014, s. 193-198.

97 Ostatnio o tym: M. Danielewski, O osadach służebnych. Uwagi historyka i archeologa na marginesie książki Iwony Nobis, „Historia Slavorum Occidentis” 10, 2016, 1, s. 266-277 (poszerzona recenzja z wykazem literatury); klasyczne: K. Modzelewski, Organizacja gospodarcza państwa piastowskiego X-XIII wiek, Wrocław 1975. 
tylko w krajach przylegających od wschodu do Rzeszy każe spojrzeć na słowiańskie kresy ówczesnych Niemiec jako obszary inspirujące reformatorów starego sposobu funkcjonowania państwa, który kończył się naszkicowanymi tu przypadkami katastrof.

Nowe rozwiązania przynosiły pewną racjonalizację systemu poboru danin, precyzyjniejsze ich określanie, co wiązało się oczywiście z bardziej intensywną eksploatacją uzależnionych od władzy obszarów. Jednakże do pewnego stopnia reformy znosiły też poprzednią zupełną uznaniowość obciążeń ludzi zajmujących się rolnictwem i wytwórczością, dlatego też były również dla nich korzystne, a to w konsekwencji dawało władzy większą stabilność.

Dociekliwy czytelnik postawi oczywiście w tym miejscu pytanie, jakie były źródła kształtowania się dawnego sposobu funkcjonowania państwa, skoro tzw. organizacja służebna związana być miała z okcydentalizacją państw Europy Środkowej ${ }^{98}$. Ryzykując dużą dozę uproszczenia, można stwierdzić, że dla Słowian pierwotny i najważniejszy impuls do organizacji państwa i wzór jego budowy wcale nie pochodził z kręgu kultury zachodnioeuropejskiej czy śródziemnomorskiej, jak często uważano, ale eurazjatyckiej, koczowniczej. Kwestia oczywiście nie jest nowa ${ }^{99}$. Tylko $\mathrm{w}$ niewielkim stopniu wiąże się z rozwijanym tu problemem, więc nie będziemy głębiej w nią wnikać, szkicują jedynie - może nieco prowokacyjnie - ogólne jej właściwości.

Zacznijmy zatem od tego, że nawet uwzględniając nowsze badania paleogenetyków dotyczące genezy Słowian, które zaprzeczają pomysłom masowej ich emigracji znad środkowego Dniepru na rzekomo opustoszałe tereny Europy Środkowej ${ }^{100}$, to i tak jest pewne - na ile możemy

98 Taką tezę postawił i wstępnie uzasadniał przed laty Sławomir Gawlas, 0 kształt zjednoczonego królestwa. Niemieckie władztwo terytorialne a geneza społeczno-ustrojowej odrębności Polski, Warszawa 2000.

${ }^{99}$ Choć z dużą ostrożnością traktujemy rosyjską eurazjatycką szkołę historyczną, to z pewnością niektórzy jej przedstawiciele wykazywali się dobrym rozeznaniem sprawy, zob. np.: O. Böss, Die Lehre der Eurasier. Ein Beitrag zur russischen Ideengeschichte des 20. Jahrhunderts, Wiesbaden 1961; S. Panarin, V. Shnirelman, Lev Gumilev, his Pretensions as a Founder of Ethnology and his Eurasian Theories, „Inner Asia” 3, 2001, s. 1-18. Szkicowo dane o państwowości koczowników wschodnioeuropejskich zestawia A. Paroń, The Nomadic State of Early Medieval Europe on the Background of the Eurasian Steppes' Political Structures. An Essay, w: „Potestas et communitas”. Interdisziplinäre Beiträge zu Wesen und Darstellung von Herrschaftverhältnissen im Mittelalter östlich der Elbe, red. A. Paroń, S. Rossignol, B.Sz. Szmoniewski, G. Vercamer, Warszawa 2010, s. 163-180; zob. także: idem, Pieczyngowie. Koczownicy w krajobrazie politycznym i kulturowym średniowiecznej Europy, Wrocław 2015, s. 158-188.

100 T. Grzybowski et al., Complex Interactions of the Eastern and Western Slavic Populations with other European Groups as Revealed by Mitochondrial DNA Analysis, „Forensis 
oczywiście mieć pewność w naukach nieweryfikowanych empirycznie że wzór kultury, również życia społecznego, szeroko pojętej duchowości oraz język, pochodził od grupy ludzi zamieszkujących w późnej starożytności i wczesnym średniowieczu teren dzisiejszej środkowo-wschodniej Ukrainy ${ }^{101}$. Wychodźcy $\mathrm{z}$ tego terenu byli w stanie $\mathrm{w}$ okresie od V do VII stulecia n.e. narzucić swój etnos rzeszom ludności zamieszkującej rozległe przestrzenie Europy Środkowej, Południowej i Wschodniej. Stało się tak dzięki kombinacji wielu czynników, które posiadali ludzie roznosiciele etniki słowiańskiej. Na pewno w pierwszym rzędzie czynnikiem umożliwiającym sukces była ich sprawność militarna. Jeśli czytamy uważnie najstarsze wiadomości zapisane o Słowianach, to wbrew dawnym stereotypowym opiniom o pokojowo-rolniczym charakterze Słowian, dostrzeżemy bez trudu treści podnoszące walory bojowe tego ludu i jego zdolność radzenia sobie z liczniejszym i lepiej uzbrojonym przeciwnikiem przede wszystkim za pomocą niekonwencjonalnych rozwiązań taktycznych. Nie bez racji podkreśla się, że umiejętności zwodzenia przeciwnika, pozorowania ucieczki i podobne zawdzięczali Słowianie kontaktom z ludami koczowniczymi, które dokonywały się na obszarach graniczących ze stepami czarnomorskimi. Tego rodzaju okoliczności wpłynęły na to, że dla wczesnośredniowiecznych Słowian to twory polityczne stworzone przez nomadów - tureckich Awarów, Chazarów czy Bułgarów miały podstawowe znaczenie wzorcotwórcze. Później podobne rozwiązania administracyjne i aprowizacyjne państwa upowszechniali wśród Słowian Rusowie-Normanowie, do początku XI w. przecież również w praktyce wiodący koczowniczy tryb życia ${ }^{102}$.

Science International: Genetics” 1, 2007, s. 141-147; A. Juras, Ancient DNA Reveals Matrilineal Continuity in Present Day Poland over the Last Two Millennia, „Plos One” 9, 2014, 10, s. 1-9, gdzie wskazuje się, że rdzeń populacji współczesnej Europy żyje w zasadzie bez większych zmian w tych samych miejscach, jakie wybrali sobie do osiedlenia się rolnicy neolityczni. Podobieństwo biologiczne nie oznacza jednakże tożsamości kulturowej, tym bardziej etnicznej dawnych i obecnych mieszkańców poszczególnych regionów naszego kontynentu; zob. także: A. Juras, „Etnogeneza Słowian w świetle badań kopalnego DNA", praca doktorska, Poznań 2012.

101 L. Leciejewicz, Nowa postać świata, s. 144-160; zob. także: P.M. Barford, Crisis in the Shadows. Recent Polish Polemic on the Origin of the Slavs, "Slavia Antiqua” 44, 2003, s. 121-155; idem, The Early Slavs, s. 35 nn.; nawet jeśli w etnogenezie Słowian jakąś rolę odgrywał obszar naddunajski, to i tak istotne w tej kwestii było znaczenie koczowników, F. Curta, The Making of the Slavs. History and Archaeology of the Lower Danube Region, c. 500-700, Cambridge 2001.

102 Wprawdzie nie wypasali oni ani bydła, ani owiec, ale przecież stale wędrowali w poszukiwaniu towarów, łupów i kontrahentów handlowych, S. Franklin, J. Shepard, The Emergence of Rus, 750-1200, London-New York 1996; także: R. Pipes, Rosja carów, s. 30 nn.; zewnętrzny splendor władzy stylizowany był oczywiście na modłę bizantyjską, 
Model państwa, który organizowali we wczesnym średniowieczu nomadzi Wielkiego Stepu ${ }^{103}$, z grubsza rzecz ujmując, różnił się od zachodnioeuropejskiego przede wszystkim jeszcze mniejszą niż tam instytucjonalizacją oraz skupieniem elit wyłącznie wokół osoby monarchy, jak również słabą obecnością władzy na całości kontrolowanego terytorium. Wskazane cechy implikowały ekstensywną eksploatacją opanowanej przestrzeni, a zwłaszcza znacznie większym niż na dawnych obszarach karolińskich nastawieniem elit państwa na doraźne łupy, zdobywane na przeciwnikach i sąsiadach, i traktowane jako jedno z kluczowych źródeł utrzymania.

Gdybyśmy zatem, konkludując, starali się podać w zwięzły sposób, jaki był charakter i znaczenie szkicowanych tu przypadków załamania się, upadku i odradzania niektórych państw środkowo-, wschodnioi południowoeuropejskich, to można byłoby zaryzykować następujące stwierdzenia. Charakter kryzysów omawianych państwowości w okresie wczesnego średniowiecza związany był z wyczerpaniem się możliwości istnienia typu państwa, którego charakter moglibyśmy określić jako państwo łupieżcze. Ponieważ władza potrafiła eksploatować uzależnione obszary jedynie w sposób ekstensywny, by trwać, potrzebowała stałych sukcesów militarnych i łupów. Ich brak oznaczał załamanie się całej struktury władzy. Odrodzenie państwowości mogło nastąpić jedynie przy spełnieniu pewnych warunków. Do tego w XI w. konieczna już była zatem chrystianizacja społeczności oraz najlepiej zorganizowanie osobnej organizacji kościelnej. Dawało to schrystianizowanym elitom państwa mocne oparcie duchowe - czynnik to w gruncie rzeczy tak samo ważny dla trwania państwa, jak sprawy materialne. Niezbędne do odrodzenia i trwania władzy było też posiadanie dynastii, również skupiającej ideowo ludzi zainteresowanych istnieniem państwa. W końcu zaś odrodzony twór polityczny miał szanse być stabilny, jeśli doszło do częściowej przynajmniej zmiany struktury aparatu administracyjnego, który eksploatował uzależnione obszary w sposób bardziej intensywny i uporządkowany.

Kryzys wymusił zatem okcydentalizację państw zachodniosłowiańskich i węgierskiego, przejście od typu państwa bezpośrednio nawiązującego do organizacji koczowników do systemu zapożyczającego pewne

P.S. Stefanovich, The Political Organization of Rus' in the 10th Century, "Jahrbücher für Geschichte Osteuropas" 64, 2016, 4, s. 529-544; Ch. Raffensperger, Reimagining Europe. Kievan Rus' in the Medieval World, Cambridge MA-London 2012, s. 10-46.

103 Л. Гумилёв, Древняя Русь и Великая степь, Москва 2006; А.Н. Поляков, Киевская Русь как изивилизации, Оренбург 2010. 
wzory monarchii wschodniofrankijskiej i niemieckiej ${ }^{104}$. Na południu słowiańskie państwa bałkańskie zmodernizowały swoje struktury administracyjne, korzystając z wzorów bizantyjskich. Do zmian niezdolne okazały się społeczności w państwach Słowian nadbałtyckich, dlatego zostały wchłonięte przez państwo niemieckie.

\section{Streszczenie}

W tekście przeprowadzono analizę kryzysów, jakie miały miejsce we wszystkich istotniejszych państwach środkowoeuropejskich w IX-XI w. Na postawie zestawienia dostępnych informacji źródłowych postawiono tezę o wzajemnie się ze sobą wiążących strukturalnych i ekonomiczno-politycznych przyczynach załamywania się państw tworzonych przez Przemyślidów, Piastów, Arpadów, Rurykowiczów i inne dynastie regionu, włączając do niego również zamieszkane przez Słowian obszary Półwyspu Bałkańskiego. Starano się udowodnić, że pojawiające się w wyżej wspomnianym czasie kryzysy państwowości środkowoeuropejskich nie były przypadkowe. Regularne przypadki załamania się w podobnym okresie organizacji politycznych wiązały się z wyczerpaniem możliwości istnienia pewnego modelu państwa. Wczesne twory państwowe charakteryzowały się bowiem specyficznym systemem aprowizacji, który ekstensywnie, nieregularnie, często rabunkowo eksploatował poddanych żyjących na określonym terenie, nie dosięgając innych obszarów podlegających nominalnie władzy. Brak przemyślanego sposobu poboru danin prowadził do ruiny tereny pozostające w bliskim zasięgu władzy oraz zmuszał elity polityczne, tożsame z militarnymi, do ciągłych wojen, mających na celu zapewnienie sobie środków do życia na odpowiednio wysokim poziomie. Dużą część przychodów dawał elitom ówczesnych państw handel niewolnikami. Zewnętrzna agresja spotykała się zawsze z odpowiedzią sąsiadów. Ciągła eskalacja przemocy zmuszała władze do zwiększania liczby wojowników, którzy - nie posiadając własności prywatnej - w całości musieli być utrzymywani przez państwo. Kryzys, zwykle też upadek tego systemu następował albo gdy władza nie była w stanie zapewnić swoim ludziom odpowiednich środków, albo gdy zbuntowały się masy poddanych rolników. Często zarzewiem szerszego buntu były walki w łonie dynastii o przywództwo, udziały i miejsce w hierarchii.

Przedstawiony model funkcjonowania władzy charakterystyczny był dla wielu wczesnych państw, ale rozwiązania funkcjonujące w środkowej Europie wywodziły się z państwowości koczowniczych. Kryzys przetrwały te organizmy polityczne,

104 Wydaje się zatem, że jest sporo racji w ogólnych tezach Thomasa N. Bissona, Iconography, Politics and the Symbolism of Power in Medieval Europe. On not eating Polish Bread in Vain. Resonance and Conjuncture in the "Deeds of the Princes of Poland” (1109-1113, „Viator" 29, 1998, s. 275-290, że kryzys lat trzydziestych XI w. w Polsce oznaczał upadek władzy o charakterze rabunkowym. Nie odnosimy się tu do kontrowersyjnych szczegółów wywodu - zob.: G. Myśliwski, op. cit., s. 94-102. 
które zdołały zmienić zasady funkcjonowania władzy i zmodernizować je, nawiązując do praktyk istniejących na obszarach dawnego państwa Franków, racjonalizujących system poboru danin.

\section{The Crisis and Collapse of Early Slavic States and Their Reconstruction (the Ninth-Eleventh Centuries). An Outline of the Problem}

The text presents an analysis of the series of crises that hit all major Central European states in the ninth to eleventh centuries. After an examination of available source material a thesis has been put forward about interrelated structural, economic and political causes which led to the collapse of the states created by the Přemyslids, Piasts, Árpáds, Ruriks and other dynasties of the region, including the area of the Balkans, inhabited by the Slavs. It is argued that the crisis of statehood in the Central European countries was not an accidental occurrence. Regular collapses in the same period of time of those political entities were caused by the exhaustion of the existing model of state. Those early states were characterized by a specific system of food provision which extensively, often wastefully, exploited their subjects living in a specific area, with the exclusion of other areas nominally falling under their sovereignty. The lack of a well thought-out manner of levying tributes brought ruin to the territories in close proximity to the power centre, and forced the political elites, identical with military ones, constantly to wage wars in order to make sufficient provisions for their life at a high level. A large part of elites' income was generated by the slave trade. External aggression was always met with a counteraction by neighbours. The constant escalation of violence forced the authorities to increase the number of warriors who - having no personal property - had to be supported by the state. A crisis, and usually a collapse of the system occurred when the rulers were unable to provide their people with sufficient livelihood, or when the masses of unfree peasants rebelled. Often it was the struggle for leadership, share and place within the hierarchy that became the source of rebellion.

The presented model of power was characteristic of many early states, but the solutions functioning in Central Europe originated from nomadic statehood. Only those political entities who were able to transform their principles of governance and modernize them on the model of practices known in the old Frankish kingdom, which rationalized the system of levying tributes, survived the crisis.

Translated by Grażyna Waluga

\section{Bibliografia}

Adamczyk Dariusz, Silber und Macht. Fernhandel, Tribute und die piastische Herrschaftsbildung in nordosteuropaischer Perspektive (800-1100), Harrassowitz, Wiesbaden 2014. Adamus Jan, Problemy absolutyzmu piastowskiego, „Czasopismo Prawno-Historyczne” 10, 1958, 2, s. 19-76. 
Banaszkiewicz Jacek, Bolesław i Predsława. Uwagi o uroczystości stanowienia władcy w zwiazku z wejściem Chrobrego do Kijowa, KH 97, 1990, 3/4, s. 3-35.

Banaszkiewicz Jacek, Podania o „Początku”, w: Dynastie Europy, red. Antoni Mączak, Ossolineum, Warszawa 1997, s. 17-45.

Barford Paul M., The Early Slavs. Culture and Society in Early Medieval Eastern Europe, Cornell University Press, Ithaca-New York 2001.

Barford Paul, Crisis in the Shadows. Recent Polish Polemic on the Origin of the Slavs, „Slavia Antiqua” 44, 2003, s. 121-155.

Berend Nora, Urbańczyk Przemysław, Wiszewski Przemysław, Central Europe in the High Middle Ages, Bohemia, Hungary and Poland c. $900-$ c. 1300, Cambridge University Press, Cambridge 2013.

Besançon Alain, Święta Ruś, Fundacja Św. Mikołaja, Warszawa 2012.

Betti Maddalena, The Making of Christian Moravia (858-882). Papal Power and Political Reality, Brill, Leiden-Boston 2013 (East Central and Eastern Europe in the Middle Ages, 450-1450, nr 24).

Bieniak Janusz, Państwo Miecława. Studium analityczne, PWN, Warszawa 1963.

Bilarsky Ivan, Word and Power in Medieval Bulgaria, Brill, Leiden-Boston 2011.

Billington James H., Ideologia moskiewska, w: Chrześcijaństwo Rusi Kijowskiej, Białorusi, Ukrainy i Rosji (X-XVII wiek), red. Jerzy Kłoczowski, PAU, Kraków 1997, s. 173-217.

Bisson Thomas N., Iconography, Politics and the Symbolism of Power in Medieval Europe. On not eating Polish Bread in Vain. Resonance and Conjuncture in the "Deeds of the Princes of Poland” (1109-1113), „Viator” 29, 1998, s. 275-290.

Boba Imre, Moravia's History Reconsidered. A Reinterpretation of Medieval Sources, Martinus Nijhoff, The Hague 1971.

Bonarek Jacek, Przyczyny i cele bułgarskich wypraw Świętosława a polityka Bizancjum w latach sześćdziesiatych X wieku, SH 39, 1996, 3, s. 287-302.

Borawska Danuta, Kryzys monarchii wczesnopiastowskiej w latach trzydziestych XI $w$. Studia, PWN, Warszawa 1964.

Boshof Egon, Das Salierreich und der europäische Osten, w: Auslandsbeziehungen unter den salischen Kaiser, red. Franz Staab, Verl. der Pfälzischen Ges. zur Förderung der Wiss. in Speyer, Speyer 1994, s. 167-192.

Böss Otto, Die Lehre der Eurasier. Ein Beitrag zur russischen Ideengeschichte des 20. Jahrhunderts, Ost-Europa Institut, Wiesbaden 1961.

Bowlus Charles R., Franks, Moravians, and Magyars. The Struggle for the Middle Danube, 788-907, University Pennsylvania Press, Philadelphia Pa. 1995.

Brüske Wolgang, Untersuchungen zur Geschichte des Lutizenbundes, Böhlau, Münster, Köln 1955 (Mitteldeutsche Forschungen 3).

Buko Andrzej, Archeologia Polski wczesnośredniowiecznej. Odkrycia - hipotezy - interpretacje, Trio, Warszawa 2005.

Buko Andrzej, Unknown Revolution. Archaeology and the Beginnings of the Polish State, w: East Central and Eastern Europe in the Early Middle Ages, red. Florin Curta, University of Michigan Press, Ann Arbor 2005, s. 162-178.

Cherniavsky Michail, „Holy Russia”. A Study in the History of an Idea, „The American Historical Review" 63, 1958, 3, s. 617-637.

Chronicarum que dicuntur Fredegarii scholastici, wyd. Bruno Krusch, MGH Script. Rer. Mer. 2, Impensis Bibliopolii Aulici Hahniani, Hannover 1888, s. 118-193. 
Ćirković Sima M., The Serbs, Blackwell, Malden Mass. 2004.

Cosmae Pragensis Chronica Boemorum, wyd. Bertold Bretholz, Berlin 1923 (MGH SrG, Nova series t. 2).

Curta Florin, Avar Blitzkrieg, Slavic and Bulgar Raiders, and Roman Special Ops. Mobile

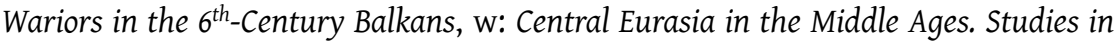
Honour of Peter B. Golden, red. István Zimonyi, Osman Karatay, Harrassowitz, Wiesbaden 2016, s. 69-90.

Curta Florin, Horsemen in Forts or Peasants in Villages? Remarks on the Archeology of Warfare to the 6th to the 7th c. Balkans, w: War and Warfare in Late Antiquity, wyd. Alexander Sarantis, Brill, Leiden-Boston 2013, s. 809-850.

Curta Florin, Slavs in Fredegar and Paul the Deacon. Medieval gens or "Scourge of God”?, „Early Medieval Europe” 6, 1997, 2, s. 141-167.

Curta Florin, The Making of the Slavs. History and Archaeology of the Lower Danube Region, c. 500-700, Cambridge University Press, Cambridge 2001.

Curta Florin, The Slavic Lingua franca (Linguistic Notes of an Archeologist Turned Historian), „East Central Europe” 31, 2004, 1, s. 125-148.

Dalewska-Greń Hanna, Języki słowiańskie, PWN, Warszawa 2012.

Dalewski Zbigniew, Modele władzy dynastycznej w Europie Środkowo-Wschodniej we wcześniejszym średniowieczu, IH PAN, Warszawa 2014.

Danielewski Marcin, O osadach służebnych. Uwagi historyka i archeologa na marginesie ksiażki Iwony Nobis, „Historia Slavorum Occidentis” 10, 2016, 1, s. 266-277.

Duczko Władysław, Ruś Wikingów. Historia obecności Skandynawów we wczesnośredniowiecznej Europie Wschodniej, Trio, Warszawa 2007.

Dux Günter, Die Genese der Sakralität von Herrschaft. Zur Struktur religiösen Weltverständnisses, w: Das frühmittelalterliche Königtum, wyd. Franz-Rainre Erkens, De Gruyter, Berlin-New York 2005, s. 9-21.

Dvornik František, The Slavs. Their Early History and Civilization, American Academy of Arts and Sciences, Boston 1956.

Eggers Martin, Das „Großmährische Reich”. Realität oder Fiktion? Eine Neuinterpretation der Quellen zur Geschichte des mittleren Donauraumes im 9. Jahrhundert, Hiersemann, Stuttgart 1995.

Engel Pál, The Realm of St. Stephen. A History of Medieval Hungary, 895-1526, I.B. Tauris, New York 2005.

Erkens Franz-Rainer, Pilgrim, Bischof von Passau, „Ostbairische Grenzmarken” 34, 1992, s. 25-37.

Felczak Wojciech, Wasilewski Tadeusz, Historia Jugosławii, Ossolineum, Wrocław 1985.

Fine John V.A., The Early Medieval Balkans. A Critical Survey from the Sixth to the Late Twelfth Century, University of Michigan Press, Ann Arbor 1991, s. 132-158.

Fonnesberg-Schmidt Iben, Papieże i krucjaty bałtyckie 1147-1254, Bellona, Warszawa 2009.

Franklin Simon, Shepard Jonathan, The Emergence of Rus, 750-1200, Longman, London-New York 1996.

Frey Christian, The Burgward Organisation in the Eastern Marches of the German Realm, w: Château Gaillard 26. Études de castellologie médiévale. Château et frontière. Actes du colloque international d'Aabenraa (Danemark, 24-31 août 2012), red. Peter Ettel, Anne-Marie Flambard Héricher, Kieran O'Conor, Brepols, Caen 2014, s. 193-198. 
Fritze Wolfgang H., Der slawische Aufstand von 983 - eine Schicksalwende in der Geschichte Mitteleuropas, w: Festschrift der landesgeschichtliche Vereinigung für die Mark Brandenburg zu ihrem hundertjährigen Bestehen, red. Eckhart Henning, Landesgeschichtliche Vereinigung für die Mark Brandenburg, Berlin 1984, s. 9-55.

Galli Anonymi Cronica et Gesta ducum sive principum oolonorum, wyd. Karol Maleczyński, PAU, Kraków 1952.

Gawlas Sławomir, o kształt zjednoczonego królestwa. Niemieckie władztwo terytorialne a geneza społeczno-ustrojowej odrębności Polski, DiG, Warszawa 2000.

Gogle Lori L., Pipes, Richard, w: Encyclopedia of Historian and Historical Writing, t. 1, red. Kelly Boyd, Fitzroy Dearborn, London 1999, s. 922.

Gołąb Zbigniew, o pochodzeniu Słowian w świetle faktów językowych, Universitas, Kraków 2004.

Grabowski Antoni, Eunuch between Economy and Philology. The Case of „carzimasium”, „Mélanges de l'École française de Rome - Moyen Âge” 127.1, 2015 - https:// mefrm.revues.org/2408.

Grzybowski Tomasz et al., Complex Interactions of the Eastern and Western Slavic Populations with other European Groups as Revealed by Mitochondrial DNA Analysis, „Forensis Science International: Genetics” 1, 2007, s. 141-147.

Havlík Lubomir E., Great Moravia between the Franconians, Byzantium and Rome, w: Centre and Periphery Comparative Studies in Archaeology, red. Tim Champion, Routledge, London-New York 1995, s. 231-240.

Havlík Lubomir, První slovanské státy. (K charakteru vládnich struktur a počátkům státnich formaci), „Slovanské historické studie” 10, 1974, s. 5-49.

Hegger Florian, Böhmen und das Reich in ottonisch-salischer Zeit, Grin, Münster 2006. Henning Joachim, Gefangenenfesseln im slawischen Siedlungsraum und der europäische Sklavenhandel im 6. bis 12. Jahrhundert, „Germania” 70, 1992, s. 403-426.

Hoffmann Hartmut, Böhmen und das Deutsche Reich im hohen Mittelalter, „Jahrbuch für die Geschichte Mittel - und Ostdeutschlands" 18, 1969, s. 1-62.

Hupchick Dennis P., The Bulgarian-Byzantine Wars for Early Medieval Balkan Hegemony. Silver-Lined Skulls and Blinded Armies, Palgrave Macmillan, Cham 2017.

Jäger Hans, Rechtliche Abhängigkeitsverhältnisse der östlichen Staaten vom Fränkisch-Deutschen Reich (Ende des 8. bis Ende des 11. Jahrhunderts), Univ. Diss., Frankfurt 1959.

Јанковиђ Ђорђе, Спрско Приморие од 7. до 10. столеђа, Srpsko arheološko društvo, Beograd 2007.

Juras Anna, „Etnogeneza Słowian w świetle badań kopalnego DNA”, praca doktorska UAM, Poznań 2012.

Juras Anna, Ancient DNA Reveals Matrilineal Continuity in Present Day Poland over the Last Two Millennia, „Plos One” 9, 2014, 10, s. 1-9.

Kara Michał, Najstarsze państwo Piastów - rezultat przełomu czy kontynuacji? Studium archeologiczne, Instytut Archeologii i Etnologii PAN, Poznań 2009.

Karwasińska Jadwiga, Drzwi Gnieźnieńskie a rozwój legendy św. Wojciecha, w: Jadwiga Karwasińska, Święty Wojciech, w: Wybór pism, [wyb. i oprac. Teresa Dunin-Wąsowicz], Towarzystwo Naukowe Warszawskie, Warszawa 1996, s. 57-84.

Keller Hagen, Zwischen regionaler Begrenzung und universalem Horizont. Deutschland im Imperium der Salier und Staufer 1024 bis 1250, Propyläen, Berlin 1986 (PropyläenGeschichte Deutschlands, red. Dieter Groh, t. 2). 
Korta Wacław, Problem niewolnictwa w Polsce wczesnośredniowiecznej, w: Społeczeństwo Polski średniowiecznej. Zbiór studiów, t. 2, red. Stefan K. Kuczyński, PWN, Warszawa 1982, s. 82-124.

Kościelak Lech J., Historia Słowacji, Ossolineum, Wrocław 2010.

Kowalska Zofia, Handel niewolnikami prowadzony przez Żydów w IX-XI wieku w Europie, w: Niewolnictwo i niewolnicy w Europie od starożytności po czasy nowożytne, red. Danuta Quirini-Popławska, Wydawnictwo UJ, Kraków 1998, s. 81-91.

Kozłowski Tomasz, Stan biologiczny i warunki życia ludności „in Culminie” na Pomorzu Nadwiślańskim (X-XIII wiek). Studium antropologiczne, Wydawnictwo Naukowe UMK, Toruń 2012.

Kronika Thietmara, wyd. Marian Z. Jedlicki, Instytut Zachodni, Poznań 1953.

Krzemieńska Barbara, Boj Knížete Břetislava I. o upevnění českého státu (1039-1041), Praha 1979 (Rozpravy Československé akademie věd 89/5, Academia).

Krzemieńska Barbara, Břetislav I. Čechy a střední Evropa v prvé polovině XI. století, Garamond, Praha 1999.

Krzemieńska Barbara, Hospodářské základy raně středověkého statú ve střední Evropě, „Hospodářské dějiny” 1978, s. 149-230.

Krzemieńska Barbara, Krize českého státu na přelomu tisíciletí, „Československẏ Časopis Historicky்" 18, 1970, 6, s. 497-532.

Kurnatowska Zofia, Grody wielkopolskie jako źródło do poznania wczesnego średniowiecza, „Wielkopolskie Sprawozdania Archeologiczne” 6, 2003, s. 10-14.

Kurnatowska Zofia, Uwagi na temat agrotechniki Słowian, „Prace i Materiały Muzeum Archeologicznego i Etnograficznego w Łodzi. Seria archeologiczna” 25, 1978, s. 221-229.

Kurnatowski Stanisław, Studia osadnicze nad struktura zasiedlenia i gospodarka, w: Ziemie polskie $w X$ wieku $i$ ich znaczenie $w$ kształtowaniu sie nowej mapy Europy, red. Henryk Samsonowicz, Universitas, Kraków 2000, s. 329-349.

Labuda Gerard, Pierwsze państwo słowiańskie. Państwo Samona, Templum, Wodzisław Śląski 2009.

Lang Henry J., The Fall of the Monarchy of Mieszko II, Lambert, „Speculum” 49, 1974, s. 623-639.

Leciejewicz Lech, Główne problemy dziejów obodrzyckich, w: Słowiańszczyzna połabska między Niemcami a Polska, red. J. Strzelczyk, Wydawnictwo Naukowe UAM, Poznań 1981, s. 167-182.

Leciejewicz Lech, Nowa postać świata. Narodziny średniowiecznej cywilizacji europejskiej, Funna, Wrocław 2000.

Leśny Jan, Konstantyn i Metody. Apostołowie Słowian. Dzieło i jego losy, Księgarnia św. Wojciecha, Poznań 1987.

Lounghis Telemachos C., Bulgaria instead of Moravia. Evidence of Major Political Changes, w: Byzantium, New Peoples. New Powers. The Byzantino-Slav Contact Zone from the Ninth to the Fifteenth Century, red. Miliana Kaimakamova, Maciej Salamon, Małgorzata Smorąg-Różycka, Towarzystwo Wydawnicze Historia Iagellonica, Kraków 2007 (Byzantina et Slavica Cracoviensia, 5), s. 63-70.

Lübke Christian, „Qui sint vel unde huc venerint”. Bemerkungen zur Herkunft der Namen von Polen und Liutizen, w: Die Suche nach den Ursprüngen. Von der Bedeutung des frühen Mittelalters, wyd. Walther Pohl, Institut für Mittelalterforschung, Wien 2004 
(Österreichische Akademie der Wissenschaften Philosophisch-Historische Klasse: Denkschriften, 322: Forschungen zur Geschichte des Mittelalters, 8), s. 279-288. Lübke Christian, Powstanie i istota związu Luciców. Jedna z konsekwencji chrystianizacji Europy Wschodniej w X stuleciu, w: Chrześcijańskie korzenie. Misjonarze, święci, rycerze zakonni (eseje i szkice), red. Sergiusz Sterna-Wachowiak, Stowarzyszenie Pisarzy Polskich, Poznań 1997, s. 51-64.

Macháček Jiří, Disputes over Great Moravia. Chiefdom or state? The Morava or the Tisza River?, „Early Medieval Europe” 17, 2009, 3, s. 248-267.

Makowiecki Daniel, Hodowla oraz użytkowanie zwierzat na Ostrowie Lednickim w średniowieczu. Studium archeozoologiczne, Muzeum Pierwszych Piastów w Lednicy, Poznań-Lednogóra 2001.

Martin Janet, Calculating Seniority and the Contests for Succession in Kievan Rus', „Russian History” 33, 2006, s. 267-281.

Martin Janet, Treasure of the Land of Darkness. The Fur Trade and its Significance for Medieval Russia, Cambridge University Press, Cambridge 1986.

Matla-Kozłowska Marzena, Pierwsi Przemyślidzi i ich państwo (od X do połowy XI wieku). Ekspansja terytorialna i jej polityczne uwarunkowania, Wydawnictwo Poznańskie, Poznań 2008.

Mauss Marcel, Szkic o darze. Forma i podstawy wymiany w społeczeństwach archaicznych, w: idem, Socjologia $i$ antropologia, PWN, Warszawa 1973, s. 107-168.

Mayr-Harting Henry, The Church of Magdeburg. Its trade and its town in the tenth and early eleventh centuries, w: Church and city 1000-1500. Essays in Honour of Christopher Brooke, red. David Abulatia, Michael Franklin, Miri Rubin, Cambridge University Press, Cambrigde 1992, s. 129-150.

Mayr-Harting Henry, Two Conversions to Christianity. The Bulgarians and the Anglo-Saxons, w: idem, Religion and Society in the Medieval West, 600-1200, Routledge, Aldershot 2010, s. 1-29.

Mikušek Eduard, Ideové pojeti vztahu českého státu k riši nemecké v dilech dejopiscu 10. a 11. stoléti, „Sbornik Historický” 26, 1979, s. 5-59.

Modzelewski Karol, Organizacja gospodarcza państwa piastowskiego X-XIII wiek, Ossolineum, Wrocław 1975.

Moravcsik Gyula, Byzantium and the Magyars, Akadémiai Kiadó, Budapest 1970.

Myers Henry, Wolfram Herwig, Medieval Kingship, Nelson-Hall, Chicago 1982.

Myśliwski Grzegorz, Feudalizm - „rewolucja feudalna” - kryzys władzy w Polsce XI poczatku XII w. Punkt widzenia mediewistyki anglojezzycznej, PH 93, 2002, 1, s. 73-102.

Novotný Václav, České dĕjiny. I/2. Od Břetislava I. do Přemysla I., Jan Leichter, Praha 1913. Ostrogorski Georgije, Dzieje Bizancjum, PWN, Warszawa 1967.

Panarin Sergei, Shnirelman Viktor, Lev Gumilev, his Pretensions as a Founder of Ethnology and his Eurasian Theories, „Inner Asia” 3, 2001, s. 1-18.

Panic Idzi, Ostatnie lata Wielkich Moraw, Wydawnictwo Uniwersytetu Śląskiego, Katowice 2003.

Paron Aleksander, Pieczyngowie. Koczownicy w krajobrazie politycznym $i$ kulturowym średniowiecznej Europy, Instytut Archeologii i Etnologii PAN, Wrocław 2015, s. $158-188$.

Paron Aleksander, The Nomadic State of Early Medieval Europe on the Background of the Eurasian Steppes' Political Structures. An Essay, w: „Potestas et communitas”. 
Interdisziplinäre Beiträge zu Wesen und Darstellung von Herrschaftverhältnissen im Mittelalter östlich der Elbe, red. Aleksander Paroń, Sébastien Rossignol, Bartłomiej Sz. Szmoniewski, Grischa Vercamer, Instytut Archeologii i Etnologii PAN, Warszawa 2010, s. 163-180.

Paszkiewicz Henryk, Wzrost potęi Moskwy, PAU, Kraków 2000.

Pelenski Jaroslaw, The Contest between Lithuania-Rus' and the Golden Horde in the Fourteenth Century for Supremacy over Eastern Europe, „Archivum Eurasiae Medii Aevi" 2, 1982, s. 300-320.

Pipes Richard, Rosja carów, Magnum, Warszawa 2006.

Pipes Richard, Żyłem. Wspomnienia niezależnego, Magnum, Warszawa 2004.

Polek Krzysztof, Państwo wielkomorawskie i jego sassiedzi, Wydawnictwo Naukowe WSP, Kraków 1994.

Polek Krzysztof, Północna i zachodnia granica państwa wielkomorawskiego $w$ świetle badań historycznych, w: Ślask i Czechy a kultura wielkomorawska, red. Krzysztof Wachowski, Mimex, Wrocław 1997, s. 9-19.

Poppe Andrzej, Svjatoslav the Glorious and the Byzantine Empire, w: Byzantium, New Peoples. New Powers. The Byzantino-Slav Contact Zone from the Ninth to the Fifteenth Century, red. Miliana Kaimakamova, Maciej Salamon, Małgorzata Smorąg-Różycka, Towarzystwo Wydawnicze Historia Iagellonica, Kraków 2007 (Byzantina et Slavica Cracoviensia, 5), s. 133-138.

Poppe Andrzej, Walka o spuściznę po Włodzimierzu Wielkim, KH 102, 1995, 3-4, s. 4-22. Pradzieje Wielkopolski. Od epoki kamienia do średniowiecza, red. Michał Kobusiewicz, Instytut Archeologii i Etnologii PAN, Poznań 2008.

Raffensperger Christian, Reimagining Europe. Kievan Rus' in the Medieval World, Harvard University Press, Cambridge MA-London 2012.

Relacja Ibrāhīma ibn Ja'kūba z podróży do krajów słowiańskich $w$ przekazie al-Bekrīego, wyd. Tadeusz Kowalski, Kraków 1946 (MPH, II/1).

Rio Alice, Slavery after Rome, 500-1100, Oxford University Press, Oxford 2017. Róna-Tas András, Hungarians and Europe in the Early Middle Ages. An Introduction to Early Hungarian History, Central European University Press, Budapest 1999.

Ruchhöft Fred, Vom slawischen Stammesgebiet zur deutschen Vogtei. Die Entwicklung der Territorien in Ostholstein, Lauenburg, Mecklenburg und Vorpommern im Mittelalter, VML Vlg Marie Leidorf, Rahden/Westfalen 2008 (Archäologie und Geschichte im Ostseeraum, t. 4).

Rühberg Nils, Niklot und der obodritische Unabhängigkeitskampf gegen das sächsische Herzogtum, „Mecklenburgische Jahrbücher” 111, 1996, s. 5-20.

S. Adalberti Pragensis episcopi et martyris vita prior, wyd. Jadwiga Karwasińska, PWN, Warszawa 1962 (MPH s.n., t. 4, fasc. 1).

Schich Walter, Die ostelbische Kulturlandschaft des 10. und 12. Jahrhunderts im Vergleich, w: Polen und Deutschland vor 1000 Jahren. Die Berliner Tagung über den „Akt von Gnesen”, wyd. Michael Borgolte, De Gruyter, Berlin 2002 (Europa im Mittelalter 5), s. 61-89.

Schmidt Roderich, Das historische Pommern. Personen, Orte, Ereignisse, Böhlau, Köln 2007.

Schmidt Roderich, Rethra. Das Heiligtum der Lutizen als Heiden-Metropole, w: Festschrift für Walter Schlesinger, t. 2, red. Helmuth Beumann, Böhlau, Köln 1974, s. 366-394. 
Schutz Herbert, The Carolingians in Central Europe, Their History, Arts and Architecture. A Cultural History of Central Europe, 750-900, Brill, Leiden-Boston 2004.

Shepard Jonathan, Slav Christianities, 800-1100, w: The Cambridge History of Christianity, t. 3: Early Medieval Christianities, c. $600-$ c. 1000, red. Thomas F.X. Noble, Julia M.H. Smith, Cambridge University Press, Cambridge 2008, s. 130-155.

Sinior Denis, The Avars, w: Cambridge History of Early Inner Asia, red. Denis Sinior [et al.], Cambridge University Press, Cambridge 1990.

Skowronek Jerzy, Tanty Mieczysław, Wasilewski Tadeusz, Historia Słowian południowych i zachodnich, PWN, Warszawa 1977.

Sláma Jiři, Slavníkovci - významná či okrajová záležitost českých dějin 10. století?, „Archeologické rozhledy” 47, 1995, 2, s. 182-224.

Śliwiński Błażej, Bezprym. Pierworodny syn pierwszego króla Polski (986 - zima/wiosna 1032), Avalon, Kraków 2014.

Slovakia in History, red. Mikuláš Teich, Dušan Kováč, Martin D. Brown, Cambridge University Press, Cambridge 2011.

Słowiańszczyzna starożytna i wczesnośredniowieczna, wyd. Gerard Labuda, PTPN, Poznań 1999.

Sobiesiak Joanna A., Bolesław II Przemyślida (†999). Dynasta i jego państwo, Avalon, Kraków 2006.

Stefanovich Petr S., The Political Organization of Rus' in the 10th Century, "Jahrbücher für Geschichte Osteuropas” 64, 2016, 4, s. 529-544.

Stepanov Tsvetelin, From "Steppe” to Christian Empire, and Back. Bulgaria between 800 and 1100, w: The Other Europe in the Middle Ages. Avars, Bulgars, Khazars and Cumans, red. Florin Curta, Brill, Leiden-Boston 2008, s. 363-377.

Stephenson Paul, Byzantium's Balkan Frontier. A Political Study of the Northern Balkans, 900-1204, Cambridge University Press, Cambridge 2004.

Stephenson Paul, The Legend of Basil the Bulgar Slayer, „Byzantine and Modern Greek Studies" 24, 2000, s. 102-132.

Strzelczyk Jerzy, Słowianie połabscy, Wydawnictwo Poznańskie, Poznań 2002.

Strzelczyk Jerzy, Zapomniane narody Europy, Ossolineum, Wrocław 2006.

Szczaniecki Michał, Powszechna historia państwa i prawa, PWN, Warszawa 1994.

Szczesiak Rainer, Auf der Suche nach Rethra! Ein interessantes Kapitel deutscher Forschungsgeschichte, w: Siedlung, Kommunikation und Wirtschaft im westslawischen Raum. Beiträge der Sektion zur slawischen Frühgeschichte des 5. Deutschen Archäologenkongresses, wyd. Felix Biermann, Thomas Kersting, Beier \& Beran, Langenweißbach 2007, s. 313-334.

Szymański Wojciech, Dąbrowska Elżbieta, Awarzy, Węgrzy, Ossolineum, Wrocław 1979. The Other Europe in the Middle Ages. Avars, Bulgars, Khazars and Cumans, red. Florin Curta, Roman Kovalev, Brill, Leiden-Boston 2008.

Tobolski Kazimierz, Środowisko przyrodnicze Europy Środkowej w czasach św. Wojciecha, w: Chrześcijańskie korzenie. Misjonarze, święci, rycerze zakonni (eseje i szkice), red. Sergiusz Sterna-Wachowiak, Stow. Pisarzy Polskich, Poznań 1997, s. 87-92.

Třeštík Dušan, Počátky Přemyslovci. Vstup Čechů do dějin (530-935), Lidové nowiny, Praha 1997.

Třeštík Dušan, Powstanie Wielkich Moraw. Morawianie, Czesi i Europa Środkowa $w$ latach 791-871, WUW, Warszawa 2009. 
Turasiewicz Adam, Dzieje polityczne Obodrzyców od IX wieku do utraty niepodległości w latach 1160-1164, Nomos, Kraków 2004.

Urbańczyk Przemysław, Early State Formation in East Central Europe, w: East Central and Eastern Europe in the Early Middle Ages, red. Florin Curta, University of Michigan Press, Ann Arbor 2005, s. 139-151.

Urbańczyk Przemysław, Początki państw wczesnośredniowiecznych w Europie Środkowowschodniej, w: Ziemie polskie wX wieku i ich znaczenie w kształtowaniu się nowej mapy Europy, red. Henryk Samsonowicz, Universitas, Kraków 2000, s. 53-70.

Urbańczyk Przemysław, Władza i polityka we wczesnym średniowieczu, Funna, Wrocław 2000.

Varga Gábor, Ungarn und das Reich vom 10. bis zum 13. Jahrhundert. Das Herrscherhaus der Árpáden zwischen Anlehnung und Emanzipation, Ungarisches Institut, München 2003.

Vlasto Alexis P., The Entry of the Slavs into Christendom. An Introduction to the Medieval History of the Slavs, Cambridge University Press, Cambridge 1970.

Wachowski Krzysztof, Pótnocny zasięg ekspansji Wielkich Moraw w świetle badań archeologicznych, w: Ślask i Czechy a kultura wielkomorawska, red. Krzysztof Wachowski, Mimex, Wrocław 1997, s. 21-23.

Wasilewski Tadeusz, Bizancjum i Słowianie w IX wieku. Studia z dziejów stosunków politycznych $i$ kulturalnych, PWN, Warszawa 1972.

Wasilewski Tadeusz, Historia Bułgarii, Ossolineum, Wrocław 1988.

Wegener Wilhelm, Böhmen-Mähren und das Reich im Hochmittelalter. Untersuchungen zur Staatsrechtlichen Stellung Böhmens und Mährens im Deutschen Reich des Mittelalters. 919-1253, Böhlau, Köln 1959.

Weinfurter Stefan, Herrschaft und Reich der Salier. Grundlinien einer Umbruchzeit, Sigmaringen, Jan Thorbecke, Sigmaringen 1992.

Wigger Friedrich, Stammtafeln des Großherzoglichen Hauses von Meklenburg, ,Jahrbücher des Vereins für Mecklenburgische Geschichte und Altertumskunde" 50, 1885, s. 111-327.

Wihoda Martin, Morava v 10. století, w: České země v raném středověku, red. Petr Sommer, Lidové noviny, Praha 2006, s. 53-73.

Żaki Andrzej, Kraków wiślański, czeski i wczesnopiastowski, w: Chrystianizacja Polski południowej. Materiały z sesji naukowej odbytej 29 czerwca 1993 roku, Secesja, Kraków 1994, s. 41-71.

Žemlička Josef, Expanze, krize a obnova Čech v letech 935-1055 (K systémovým proměnám raných států ve střední Evropě), „Česky் časopis historicky்” 93, 1995, s. 205-222.

Zimmermann Gerd, Wolfgang von Regensburg und die Gründung des Bistums Prag, w: Tausend Jahre Bistum Prag 973-1973. Beiträge zum Millenium, wyd. Ernst Kumzmann, Adolf Nittner, Ackermann-Gemeinde, München 1974, s. 70-92.

Гумилёв Лев, Древняя Русь и Великая степь, Эксто, Москва 2006.

Красильников Кнрнл И., Новые даные об етническом составе населения Степного Подониовия в VIII - нач. Х в., w: Степи Европы в епоху средневековя, t. 2: Хазарские времия, red. Комитет, Донецк 2001, s. 303-322.

Повесть временных лет, wyd. Дмитрий С. Лихачев, cz. 1, Академия Наук СССР, Москва-Ленинград 1950. 
Поляков Александр Н., Киевская Русь как ц̧ивилизац̧ия, ОГУ, Оренбург 2010. Пресняков Александр Е., Княжое право в древней Руси. Очерки по истории X-XII столетий. Лекции по русской истории, Киевская Русь, Наука, Москва 1993. Русина Олена, Україна під татарами і Литвою, Альтернативи, Київ 1998. Филист Георгий М., История „преступлений” Святополка Окаянного, Беларусь, Минск 1990.

Biogram: Andrzej Pleszczyński, prof. dr hab., zatrudniony w Instytucie Historii UMCS w Lublinie, zainteresowania naukowe: relacje polsko-czesko-niemieckie we wcześniejszym średniowieczu; podłoże historyczne i kulturowe stereotypów narodowych; ideologia władzy w średniowieczu; kontakt: a.pleszczynski@poczta.umcs. lublin.pl. 